\title{
WHO LET THE SECRETS OUT? OVERCONFIDENCE AND THE DISCLOSURE OF PROPRIETARY INFORMATION
}

\author{
by \\ CALEB RAWSON \\ B.S., Colorado Christian University, 2013 \\ A thesis submitted to the \\ Faculty of the Graduate School of the \\ University of Colorado in partial fulfillment \\ of the requirement for the degree of \\ Doctor of Philosophy \\ Department of Accounting
}

2018 
This thesis entitled:

Who Let the Secrets Out? Overconfidence and the disclosure of proprietary information. written by Caleb Rawson

has been approved for the Department of Accounting

Jonathan Rogers

Sarah Zechman

Date

The final copy of this thesis has been examined by the signatories, and we find that both the content and the form meet acceptable presentation standards of scholarly work in the above mentioned discipline. 
Rawson, Caleb (Ph.D., Accounting)

"Who Let the Secrets Out? Overconfidence and the disclosure of proprietary information" Thesis directed by Professor Jonathan Rogers and Associate Professor Sarah Zechman

This dissertation investigates how CEO overconfidence is associated with the disclosure of proprietary information. I use characteristics of research and development activities (R\&D) and capital investments (CAPX) to examine within-firm variation in proprietary disclosure costs. After verifying that narrative disclosures about R\&D have higher levels of proprietary disclosure costs than those about CAPX, I predict that overconfident executives underestimate the costs of disclosing proprietary information, leading to higher proprietary disclosure. Consistent with this prediction, I find that overconfident CEOs disclose significantly more about R\&D, but not more about CAPX. Further, these CEOs increase the disclosure of distinctly proprietary R\&D information (i.e., about current and future investments) significantly more than less proprietary R\&D information (i.e., about historical investments). The results suggest the findings are not due to endogenous firm-CEO matching or overconfident CEOs selecting systematically different investment levels. 


\section{ACKNOWLEDGEMENTS}

I thank my dissertation committee: Jonathan Rogers (co-chair), Sarah Zechman (cochair), Tony Cookson, Yonca Ertimur, and Alan Jagolinzer for their guidance and support. Their suggestions and advice have been invaluable in shaping this dissertation. I am also grateful to the University of Colorado accounting faculty and $\mathrm{PhD}$ students for their help and support throughout the entire PhD process over the last several years. This project has also directly benefited from helpful comments and suggestions from Kris Allee, Leah Baer, Tony Ding, Nathan Marshall, Steven Rock, Nikki Skinner, Andy Stephan, Jake Thornock, Frances Tice, and workshop participants at the University of Arkansas, the University of Colorado, and the 2017 American Accounting Association/Deloitte/J. Michael Cook Doctoral Consortium.

I am immensely indebted to Tamera Hannaway, Chris Leland, William Mesa, and the late Ray Ostle for putting me on the path to pursing a PhD. Without their prodding, encouragement, and support, I never would have begun this process in the first place.

Finally, I simply could not have done this without my wife Sarah and her abundant enthusiasm and encouragement throughout the past several years. 


\section{CONTENTS}

\section{CHAPTER}

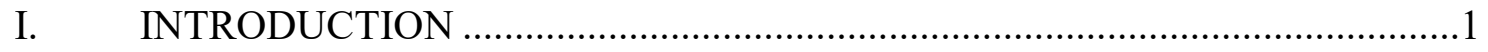

II. RELATED LITERATURE AND HYPOTHESIS DEVELOPMENT ..................7

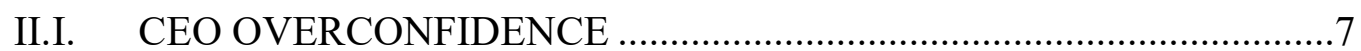

II.II. THE EFFECT OF OVERCONFIDENCE ON PROPRIETARY

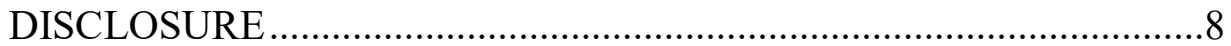

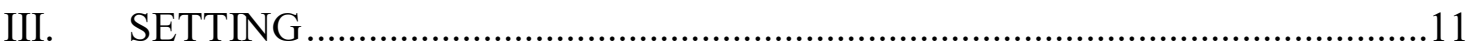

IV. SAMPLE SELECTION AND SETTING VALIDATION .................................14

IV.I. MEASURING DISCRETIONARY INVESTMENT DISCLOSURE ...14

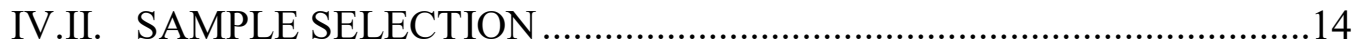

IV.III. SETTING VALIDATION ….......................................................................

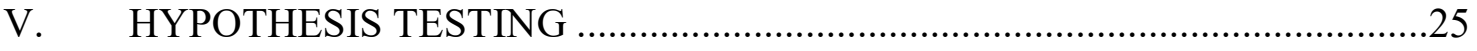

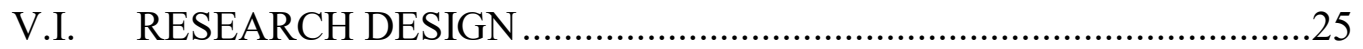

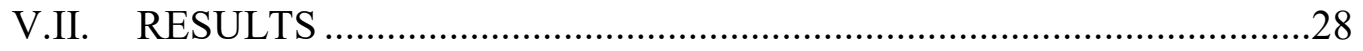

V.III. ADDITIONAL ANALYSIS - DISCLOSURE CONTENT......................33

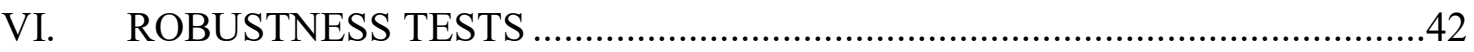

VI.I. CEO-FIRM MATCHING ................................................................

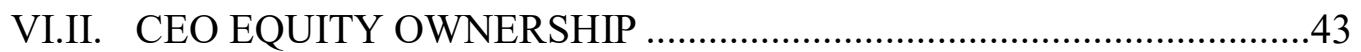

VI.III. SIGNIFICANT INVESTMENT LEVELS .............................................43

VI.IV NEW PRODUCT ANNOUNCEMENTS ...............................................44

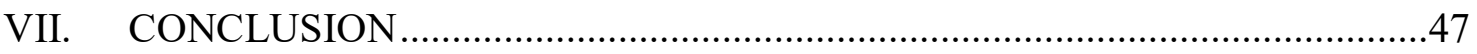


APPENDIX

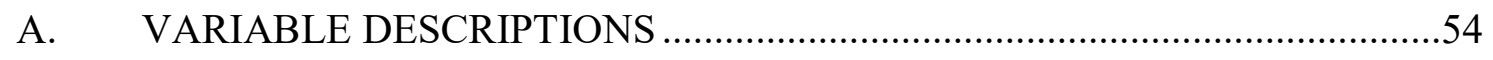

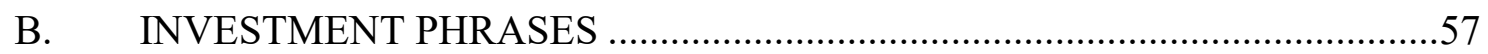

C. PROPENSITY SCORE MATCHING ANALYSIS ......................................59 


\section{TABLES}

Table

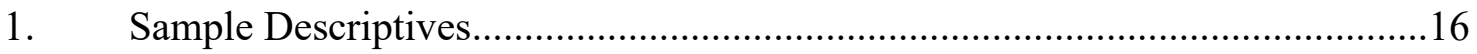

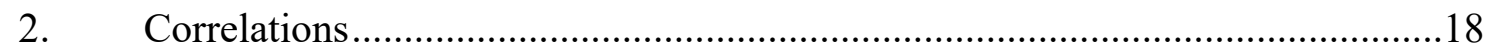

3. Competitive Environment and Proprietary Disclosure Costs ..........................21

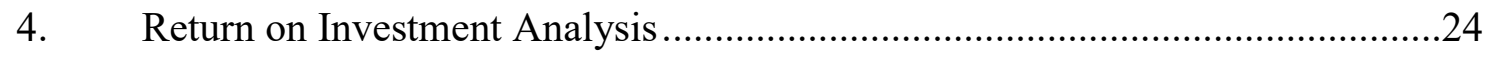

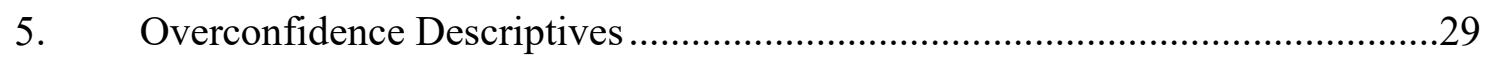

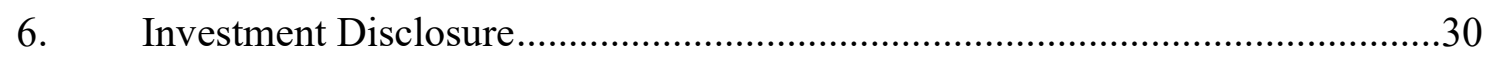

7. Investment Disclosure - Propensity Score Matching .....................................32

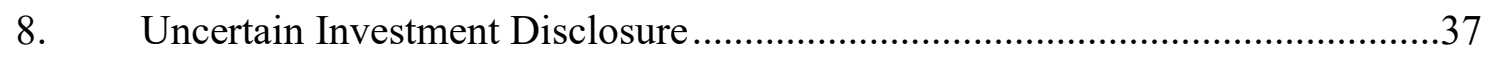

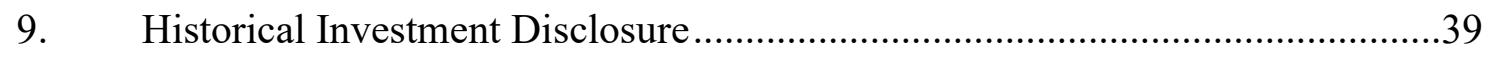

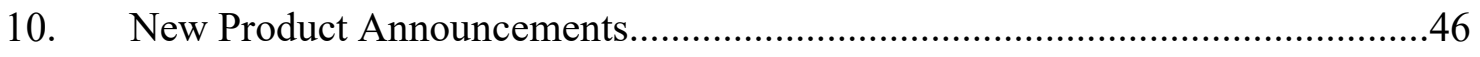

C1. Propensity Score Matching - First Stage ..................................................61

C2. Additional Propensity Score Matching Models ............................................62 


\section{CHAPTER I}

\section{INTRODUCTION}

Proprietary costs act as a deterrent for voluntary disclosure and prevent full disclosure from occurring (Verrecchia [1983]). Firms operating in environments with greater proprietary costs have fewer management forecasts (X. Li [2010]), greater redaction of sensitive information (Boone, Floros, and Johnson [2016]), and are less likely to disclose information about profitable segments (Harris [1998]). While extensive research has examined how firm characteristics and information environments are associated with voluntary disclosure of proprietary information (see Beyer, Cohen, Lys, and Walther [2010] for a review), little is known about whether and how CEO characteristics are associated with voluntary disclosure of proprietary information. Prior literature has established that $\mathrm{CEO}$ overconfidence is an important managerial trait due to overconfidence being associated with unrealistically certain and positive beliefs about the future. This study examines whether overconfidence influences perceived proprietary disclosure costs, thereby resulting in greater voluntary disclosure of proprietary information. ${ }^{1}$

Laboratory and field studies in psychology and behavioral economics show that overconfidence is an important attribute affecting an individual's perception of themselves, others, and the future. ${ }^{2}$ Research in accounting and finance has documented that CEO overconfidence is associated with firm decisions (e.g., investment levels and acquisitions, see

\footnotetext{
${ }^{1}$ Proprietary disclosure costs refer to costs associated with the voluntary disclosure of private information that are realized predominantly through worse future performance. For example, disclosing an R\&D breakthrough may result in a rival firm using the information to develop a competing project, leading to greater competition and worse future performance for the disclosing firm.

${ }^{2}$ For examples, see Moore and Cain (2007) and Anderson, Brion, Moore, and Kennedy (2012). See Skała (2008) for a more in-depth review of the psychological underpinnings of overconfidence and potential implications for financial markets.
} 
Malmendier and Tate [2015] for a review) and financial reporting (e.g., Schrand and Zechman [2012] look at financial misreporting while Ahmed and Duellman [2013] examine accounting conservatism). I expect two specific facets of overconfidence, overoptimism and miscalibration, to influence managers when deciding whether to disclose information with potential proprietary disclosure costs. Overoptimism (also called overestimation) is associated with holding an unrealistically positive view of the future (i.e., a mean effect). Overoptimistic CEOs may believe that the benefits of disclosing proprietary information are greater than they actually are while simultaneously underestimating the costs. Miscalibration is associated with holding an unrealistically certain view of the future by overestimating the certainty of future events (i.e., a variance effect) or altering the expected probability of possible outcomes (i.e., a skew effect). Miscalibrated CEOs may believe that the risk of rivals appropriating disclosed proprietary information is lower than reality, leading to increased disclosure of proprietary information. Thus, I hypothesize that overconfidence is associated with greater disclosure of proprietary information.

To examine proprietary disclosure behavior, I investigate the narrative disclosure of research and development (R\&D) and capital investments (CAPX) in the 10-K. I focus on narrative investment disclosures for two reasons. First, the amount of reported CAPX and R\&D expense is unlikely to allow stakeholders to accurately value and understand the investments of a firm. Voluntary disclosures can help bridge the gap between numbers conveyed in financial statements and the underlying investment activities of the firm (Merkley [2014]; Beyer, Herrmann, and Rapley [2015]). Second, I expect different types of investments (R\&D versus CAPX) to have different levels of proprietary disclosure costs (e.g., information spillovers) for the same firm. This allows me to examine how the presence of an overconfident CEO is 
associated with variation in the disclosure of investments with different levels of proprietary costs, holding the firm and disclosure document constant.

I begin my analysis by validating that narrative $R \& D$ disclosures have greater proprietary disclosure costs than narrative CAPX disclosures in two ways. First, proprietary disclosure costs arise from a combination of how costly the disclosed information would be if used by a rival firm and how likely rival firms are to use the disclosed information (i.e., there is both an information component and a competition component). An increase in the likelihood that rivals will use the information will result in a decrease in the amount of disclosure. The costlier information is if used by a rival firm, the greater the decrease. Thus, if R\&D disclosures have greater proprietary disclosure costs than CAPX disclosures, then as competition increases managers should decrease R\&D disclosure more than CAPX disclosure. I find that firms in more competitive environments have significantly less disclosure of R\&D per dollar of investment then firms in less competitive environments. I do not find similar results for CAPX disclosure. This is consistent with managers perceiving the proprietary disclosure costs of $R \& D$ to be greater than those of CAPX.

Second, if R\&D disclosures are costlier due to rivals appropriating information, then firms with high amounts of $R \& D$ disclosures will have a lower return on the underlying $R \& D$ in comparison to firms with lower amounts of R\&D disclosures (similar results will not exist for CAPX if CAPX disclosures do not provide rivals with information to appropriate). I find evidence consistent with this proposition, which provides further support that R\&D disclosures have greater proprietary disclosure costs than CAPX disclosures.

Next, I examine how the presence of an overconfident CEO is associated with discretionary investment disclosure. If overconfident CEOs overestimate the benefits of 
disclosure, then firms with overconfident CEOs will have more of both R\&D and CAPX disclosures compared to firms without an overconfident $\mathrm{CEO} .^{3}$ Alternatively, if overconfident CEOs underestimate proprietary disclosure costs, then firms with overconfident CEOs will have more R\&D disclosures, but not more CAPX disclosures, than firms without an overconfident CEO (due to CAPX disclosures already having low proprietary disclosure costs). Following prior literature (Hribar and Yang [2016]; Kim, Wang, and Zhang [2016]), I use two different proxies to identify overconfident CEOs. The first proxy examines CEOs' stock option exercising behavior while the second proxy looks at firm decisions made during the CEOs' tenures. I find that overconfident CEOs provide approximately 9\% more R\&D disclosures than nonoverconfident CEOs, but CAPX disclosures do not differ. These results are robust to a variety of alternative specifications addressing concerns related to industry biases, endogenous selection of investment levels, functional form misspecification, and endogenous CEO-firm matching.

Finally, I examine the content of investment disclosures to see whether the R\&D disclosures made by overconfident CEOs contain more distinctly proprietary information. First, I classify disclosures by whether they contain uncertain information and test whether overconfident CEOs increase uncertain $\mathrm{R} \& \mathrm{D}$ disclosures more than non-uncertain $\mathrm{R} \& \mathrm{D}$ disclosures. I find only weak evidence that this proposition is true. Second, I classify disclosures by whether they are about predominantly historical investment activities or current and future (i.e., non-historical) investment activities (based on the view that non-historical investment activities contain more proprietary information, on average, than historical investment activities).

I find strong evidence that overconfident CEOs increase the disclosure of non-historical R\&D

${ }^{3}$ The underlying presumption is that R\&D and CAPX disclosures have at least some benefit (see Section 3 for further discussion on this). Importantly, they do not need the same benefit for this outcome to be observed. 
activities significantly more than the disclosure of historical $\mathrm{R} \& \mathrm{D}$ activities. This is consistent with overconfidence being associated with lower perceived proprietary disclosure costs, leading to more disclosure of proprietary information.

This study makes three main contributions to prior literature. First, I extend the literature on CEO overconfidence by showing that overconfidence is associated with more disclosure of proprietary information. There is a lack of consensus in the accounting and finance literature about whether overconfidence is a preferable CEO trait. For example, CEO overconfidence has been found to be associated with distorted capital investments and more acquisitions (Malmendier and Tate [2005, 2008]), suggesting suboptimal investment decisions. However, overconfidence has also been found to be associated with more and better patents (e.g., Galasso and Simcoe [2011], Hirshleifer, Low, and Teoh [2012]). ${ }^{4}$ Recent research (e.g., Glaeser et al. [2017], Saidi and Žaldokas [2017]) has argued that the decision to patent is often a disclosure decision, and not just an innovation outcome, making it difficult to parse out the underlying reason for why firms pursue patents. ${ }^{5}$

This study contributes to the debate on the costs and benefits of having an overconfident CEO by showing that firms with overconfident CEOs disclose more proprietary information, potentially harming future firm performance. This is consistent with overconfident CEOs patenting more without investing in higher quality $R \& D$ and is in contrast to the interpretation in Galasso and Simcoe (2011) and Hirshleifer et al. (2012) that overconfident CEOs are better

${ }^{4}$ Other recent research has also focused on the "bright-side" of overconfidence by showing, for example, that overconfident CEOs are better leaders (Phua, Tham, and Wei [2018]).

${ }^{5}$ This stems from patent applications being published well before a patent is granted, inducing significant disclosure costs in the event that the patent is not granted. Even if a patent is granted, law research finds that as many as $74 \%$ of patentees lose if a patent is challenged in court (Allison, Lemley, and Schwartz [2014]) and district courts only upheld patents in 35\% of cases (PricewaterhouseCoopers [2016]). Private conversations with two patent attorneys confirmed that practitioners also often view a patent application as a disclosure choice. 
innovators. Instead of overconfidence being associated with more innovation like prior research has argued, I find that it is associated with more disclosure of innovation after controlling for the amount of underlying investment.

Second, the results in this paper have implications for research on investment disclosure more broadly. Prior research has examined the association between investment disclosure and firm specific factors such as upcoming seasoned equity offerings (Glaeser et al. [2017]) and earnings (Merkley [2014]). However, little is known about the role of managerial characteristics in this setting. This study provides initial evidence that CEO characteristics, specifically overconfidence, play a role in determining the amount of investment disclosure that firms provide. Further, there has been limited research on CAPX disclosure and this study provides the first large-scale empirical examination of CAPX disclosure.

Finally, this study responds to the call made by Beyer et al. (2010) for more research on the importance of proprietary costs for disclosure decisions. Conceptually, disclosures have higher proprietary costs if the information is more useful to a firm's rivals, and rivals use the information to hurt the disclosing firm. In contrast to prior studies that use management forecasts as a proxy for the disclosure of proprietary information (e.g., X. Li [2010]; Huang, Jennings, and $\mathrm{Yu}$ [2017]), I examine voluntary disclosures of investment information which allows for examining variation in the proprietary costs of disclosures made within the same document. These disclosures (especially about $\mathrm{R} \& \mathrm{D}$ ) convey information that is useful to rival firms when making decisions that could hurt the disclosing firm in the long term. 


\section{CHAPTER II}

\section{RELATED LITERATURE AND HYPOTHESIS DEVELOPMENT}

\section{II.I. CEO OVERCONFIDENCE}

Personality traits have been found to be important factors for a wide range of behavior. Overconfident tendencies, in particular, have been found to be associated with behavioral phenomena ranging from war (Johnson [2004]) to entrepreneurial behavior (Koellinger, Minniti, and Schade [2007]). Within the accounting and finance literature there has been a notable amount of research about the implications of having a CEO who is overconfident. Using an analytical model, Heaton (2002) shows that managers who are too optimistic (i.e., overconfident) mistakenly invest in negative NPV projects perceiving them to be positive NPV projects. Empirical literature has found evidence suggesting that overconfident CEOs are associated with a variety of firm behaviors and decisions, including investment levels and acquisitions (Malmendier and Tate [2005, 2008]) and patenting (Galasso and Simcoe [2011]; Hirshleifer et al. [2012]).

Recent studies in accounting have examined how the presence of an overconfident CEO is associated with financial reporting decisions. Specifically, firms with overconfident CEOs are more likely to intentionally misstate financial information (Schrand and Zechman [2012]), report discretionary levels of R\&D expense on the financial statement (Koh, Reeb, and Zhao [2018]), and have less conservative accounting (Ahmed and Duellman [2013]). However, little is known 
about how overconfidence may alter voluntary disclosure and the role of the CEO in determining the extent and content of proprietary disclosures. ${ }^{6}$

\section{II.II. THE EFFECT OF OVERCONFIDENCE ON PROPRIETARY DISCLOSURE}

When managers decide how much voluntary information to disclose, they face a tradeoff when the information may be used by rival firms, especially in a manner which may hurt the disclosing firm. On the one hand, firms usually benefit from disclosure via reduced information asymmetry and investor uncertainty. However, this may come at the cost of aiding rival firms by providing proprietary information about the firm's products, strategy, or future plans. While extensive research has examined this cost-benefit tradeoff (e.g., Boone et al. [2016]; Ellis, Fee, and Thomas [2012]), one key aspect remains uncertain: What role does manager perception of proprietary costs play in the disclosure decision?

In the presence of perfect information and accurate perception, a CEO will only voluntarily disclose information if the benefits of disclosure outweigh the costs of disclosure. To the extent that overconfidence alters the perceived costs or benefits of disclosure, overconfidence may also alter the amount and type of information that CEOs voluntarily disclose.

While psychology and behavioral economics literatures have identified several facets of overconfidence, two are especially important for this study since they are likely to alter the perceived costs and benefits of voluntary disclosure. First, overoptimism (or overestimation) is associated with holding an unrealistically positive view of uncertain future outcomes (i.e., a mean effect). This suggests that overconfident CEOs will overestimate the potential benefits of

\footnotetext{
${ }^{6}$ The main exception is that firms with overconfident CEOs provide management forecasts that are more optimistic, more precise, and more likely to be missed (Hilary and Hsu [2011]; Hribar and Yang [2016]).
} 
disclosure while simultaneously underestimating the potential costs, leading to more disclosure of information with proprietary costs that would otherwise be withheld. If overconfidence primarily influences the perceived benefits of disclosure and not the perceived costs of disclosure, overconfident CEOs may also disclose more information without proprietary costs due to perceiving the benefits to be greater.

Second, miscalibration is associated with individuals underestimating the uncertainty of future events or altering the expected probability of possible outcomes (i.e., a variance or skew effect). This suggests that overconfident CEOs will underestimate the risk associated with rivals appropriating proprietary information (or other negative outcomes of proprietary disclosure), leading to increased disclosure of information with proprietary costs (e.g., knowledge spillover risk) and not increased disclosure of non-proprietary information (which already has low perceived disclosure costs). This may also lead to relatively more disclosure of proprietary information (which has a greater ex ante risk of negative outcomes) than non-proprietary information.

In developing my hypothesis, I rely on the effects of both overoptimism and miscalibration. However, similar to prior empirical studies examining overconfidence, I cannot differentiate between these two facets of overconfidence to determine which is the predominant driver of any observed association between overconfidence and proprietary disclosure.

While it is possible that overconfident CEOs will disclose more of both proprietary and nonproprietary information (due to greater perceived benefits of disclosure), I hypothesize that the effects of overconfidence to impact the disclosure of only proprietary information for two reasons. First, if there are no (or low) disclosure costs then, as long as there is some benefit to disclosure, information will be disclosed regardless of how great the perceived benefit of 
disclosure is. Thus, perceiving a non-proprietary piece of information to have greater benefits will not result in additional disclosure. Second, one of the most significant reasons why executives do not disclose information is proprietary costs (Graham, Harvey, and Rajgopal [2005]). This means that disclosures with greater proprietary costs will be withheld more frequently, allowing for there to be more variation in perceived disclosure costs and thus perception plays a greater role in deciding what to disclose. Thus, I hypothesize that overconfidence is associated with more disclosure of proprietary information, but not more disclosure of non-proprietary information. 


\section{CHAPTER III}

\section{SETTING}

The setting of $10-\mathrm{K}$ narrative investment disclosures has several advantages for testing my hypothesis. First, the $10-\mathrm{K}$ provides a reliable and consistent setting to analyze disclosures made by the firm. Prior literature has argued that the $10-\mathrm{K}$ contains or proxies for important information that is useful to a variety of firm stakeholders (Brown and Tucker [2011]; Lehavy, Li, and Merkley [2011]). While it is unlikely that CEOs have sole discretion over disclosures in the $10-\mathrm{K}$, prior literature has found that CEOs influence $10-\mathrm{K}$ disclosures. For example, firms with founder CEOs have been found to have more optimistic and uncertain $10-\mathrm{K}$ disclosures (Hendricks, Lang, and Merkley [2017]).

Second, for most public firms, investment decisions are key to sustaining and improving profitability and growth (Klette and Griliches [2000]). As such, communicating the value of a firm's investments to current and potential investors is important (Jones [2007]; Ciftci and Zhou [2016]). Mandatory quantitative investment disclosures (e.g., R\&D expense) are not sufficient to fully communicate this information for three reasons. First, investments are either immediately expensed or are capitalized with a depreciation rate that may not be observable to investors or accurately represent the underlying value. ${ }^{7}$ Second, future cash flows from investments can be difficult to forecast, making it challenging for managers to know what effective and credible quantitative disclosure would be. Finally, investments that do not simply replace current assets

${ }^{7}$ Jackson (2008) and Jackson, Liu, and Cecchini (2009) find both experimental and empirical evidence suggesting that depreciation methods affect managers' investment decisions. This lends support to the view that depreciation rates do not result in a book value that fully represents the value of the underlying investment and can alter managers' perceived value of capital investments. 
can have high levels of information asymmetry and risk associated with them that quantitative accounting measurements cannot effectively communicate (Palmon and Yezegel [2012]).

Because quantitative investment disclosures are not sufficient for investors to appropriately value the firm, managers also make discretionary narrative disclosures to aid in investor valuation. Prior literature has found that managers provide more discretionary R\&D disclosures when investors are more likely to need additional information (Entwistle [1999]; Merkley [2014]), when the timing is opportunistic such as before a seasoned equity offering (Glaeser et al. [2017]), or before adverse R\&D outcomes are observed (James and Shaver [2016]). Further, analysts have more accurate forecasts when firms disclose more about R\&D investments (Jones [2007]; Merkley [2014]), providing evidence that investment disclosures are useful to stakeholders. The limited literature on CAPX disclosures finds evidence that, similar to R\&D, voluntary disclosure is also helpful to investors. Specifically, Beyer et al. (2015) find evidence suggesting that voluntarily disaggregating CAPX into maintenance and growth components can help investors better predict future sales, while Cole and Jones (2015) find that CAPX and store opening forecasts by retail firms are incrementally informative when predicting future $\mathrm{CAPX}^{8}$

Holding the firm and disclosure document constant, I expect the proprietary costs of narrative investment disclosures to vary systematically with the type of investment being disclosed. Knowledge spillover and perceived proprietary costs are significant concerns for

\footnotetext{
${ }^{8}$ One potential concern is that discretionary investment disclosures are often ex-ante unverifiable by firm stakeholders. This can potentially create a "cheap talk" setting where investors perceive observed discretionary disclosure as managers "hyping" the firm. However, the presence of proprietary disclosure costs impacts this in two ways. First, if proprietary disclosure costs exist, managers will only disclose a piece of information if they perceive the benefits to be greater than the proprietary costs (Verrecchia [1983], Dye [1986]). Second, due to the presence of proprietary disclosure costs, managers will not disclose information unnecessarily (and thus hurt the firm), allowing for ex-ante unverifiable disclosures to gain credibility (Gigler [1994]).
} 
managers when deciding what and how much to voluntarily disclose (Graham et al. [2005]; Dedman and Lennox [2009]). Proprietary disclosure costs arise from a combination of both how costly the disclosed information would be if used by a rival firm and how likely rival firms are to use the disclosed information.

$\mathrm{R} \& \mathrm{D}$ related information may contain more growth-oriented information on average than CAPX related information, which contains information about both the maintenance (e.g., repairs and replacement) and growth of capital investments. To the extent that growth-oriented information is more likely to lead to knowledge spillovers, $R \& D$ disclosures will have greater spillover risk than CAPX disclosures. Indeed, while prior research has established that R\&D has non-trivial knowledge spillovers (Bloom, Schankerman, and Van Reenen [2013]), there has been no prior research examining whether CAPX disclosures result in knowledge spillover. Because of less growth oriented and forward-looking information on average, I expect there to be a relatively lower likelihood of knowledge spillovers for CAPX disclosure. Thus, I expect that narrative $\mathrm{R} \& \mathrm{D}$ disclosures will have greater proprietary disclosure costs than narrative CAPX disclosures. $^{9}$

If the hypothesis that overconfidence leads to additional proprietary disclosures is true, firms with overconfident CEOs should have more narrative R\&D disclosures in the $10-K$, but not more narrative CAPX disclosures, when compared to firms without an overconfident CEO.

${ }^{9}$ It does not need to be the case that CAPX disclosures do not have any proprietary costs associated with them, but that, on average, they have lower proprietary costs than R\&D disclosures. 


\section{CHAPTER IV}

\section{SAMPLE SELECTION AND SETTING VALIDATION}

\section{IV.I. MEASURING DISCRETIONARY INVESTMENT DISCLOSURE}

I measure discretionary investment disclosure by examining the amount of investment disclosure in firms' 10-Ks. Consistent with prior literature (Merkley [2014]), I count the number of sentences in the $10-\mathrm{K}$ that contain investment related phrases (Appendix B provides the list of investment phrases). ${ }^{10}$ This method of measuring investment disclosure has the advantage of allowing for consistent measurement of a broad range of firms over a long time period. Further, this also allows for the comparison of investment disclosures across firms, even when they do not disclose investment related information via press releases, 8-Ks, or report the amount of investment on their financial statements (Koh and Reeb [2015]). Finally, using a sentence-based measure has the added benefit of potentially more accurately identifying "pieces" of information that are disclosed, compared to word-based methods which capture the intensity of disclosure.

\section{IV.II. SAMPLE SELECTION}

My sample includes all firm-year observations with data in Compustat, CRSP, and ExecuComp and fiscal years from 2001 to 2015. My sample starts in 2001 to ensure that the disclosure environment for investments remains consistent. In November 2000 the United States

${ }^{10}$ Using Python, I parse each 10-K into individual sentences and then search each sentence for the presence of one or more R\&D or CAPX phrase. I exclude all exhibits, except exhibit 13 (commonly the MD\&A), as they are more likely to contain disclosures that do not change and are not relevant for investment disclosures (e.g., executive employment contracts). 10-Ks cleansed of HTML data and numerical tables are obtained from the University of Notre Dame's Software Repository for Accounting and Finance (sraf.nd.edu). See Loughran and McDonald (2016) for a review of the textual analysis literature and an overview of important nuances. 
Patent and Trademark Office began publishing patent applications, allowing for an alternative R\&D disclosure channel. Further, the implementation of Reg FD in 2000 may have also altered the disclosure channels given that Reg FD restricted managers' ability to selectively disclose private information. I exclude utilities and financial institutions due to the regulatory nature of those industries. I further require that firms file a $10-\mathrm{K}$ and have stock prices available three months after the fiscal year. For ease of interpretation, I classify firms as being a High_Discloser if they are in the top tercile of investment disclosure in their year and industry. ${ }^{11}$

Table 1 provides descriptive statistics for the entire sample and for the subsets of R\&D and CAPX High_Discloser firms. All variables are winsorized at the $1^{\text {st }}$ and $99^{\text {th }}$ percentile to reduce the effect of outliers. I scale investments and other control variables by assets excluding net property plant and equipment to ignore biases arising from investment activities systematically affecting the denominator (i.e., both R\&D and CAPX are treated similarly and do not increase adjusted assets at the time of investment). ${ }^{12}$ Sample firms tend to be large and rightskewed with mean (median) adjusted assets of \$6 (\$1) billion. High R\&D disclosing firms have a lower book-to-market ratio and lower leverage while high CAPX disclosing firms have a higher book-to-market ratio and higher leverage. Finally, high R\&D disclosing firms are more likely to have a CEO identified as being overconfident using both proxies of overconfidence.

${ }^{11}$ My primary measure of industry is Fama-French 48 classifications. My results are robust to alternatively using Fama-French 12 classifications, and two- or three-digit SIC codes.

12 There is no standard method of scaling investment levels in prior literature. For example, prior literature has scaled R\&D by operating expenses (Merkley [2014]), sales (Jones [2007]), assets (Curtis, McVay, and Toynbee [2017]), and market value (Lev, Radhakrishnan, and Tong [2016]). Scaling investment by market value can be problematic in this setting as it incorporates the market's expectation of future investment value, which results in high-valued investments being under-weighed and is influenced by disclosure choices. Scaling by sales or operating expenses can be problematic as it overweighs firms that are still in a growth stage (a notable number of R\&D intense firms). Scaling by assets results in the denominator being systematically associated the type of investment as, unlike CAPX, $R \& D$ decreases assets at the time of expenditure. 
TABLE 1

Sample Descriptives

This table reports the mean, median, and standard deviation of firm characteristics for the full sample, the subset of high R\&D disclosing firms, and the subset of high CAPX disclosing firms. Firms are identified as being a high disclosing firm if they are in the top tercile of discretionary investment disclosure for their year and industry. Due to multiple firms having the same level of disclosure as the top tercile threshold, the number of observations for High_Discloser firms are not equal to exactly one third of the full sample. Adjusted assets, market value, revenue, and disclosure variables are reported as the unlogged amount for descriptive purposes only. All variables are winsorized at the $1 \%$ and $99 \%$ level. $* * *$, and $* * *$ represent significant differences at the $10 \%, 5 \%$, and $1 \%$ level between High_Discloser and non-High_Discloser firms in means (medians) from a two-sided t-test (Wilcoxon rank-sum test). For binary variables, significance in means comes from a $\chi^{2}$ test.

\begin{tabular}{|c|c|c|c|c|c|c|c|c|c|c|c|c|}
\hline \multicolumn{5}{|c|}{ Full Sample } & \multicolumn{4}{|c|}{ High R\&D Disclosers } & \multicolumn{4}{|c|}{ High CAPX Disclosers } \\
\hline & $\mathbf{N}$ & Mean & Median & SD & $\mathbf{N}$ & Mean & Median & SD & $\mathbf{N}$ & Mean & Median & SD \\
\hline Adjusted Assets & 22,467 & 6,339 & 1,133 & 18,010 & 6,488 & $8,067 * * *$ & $1,020^{*}$ & 22,028 & 6,774 & $5,999 *$ & $1,387 * * *$ & 16,079 \\
\hline Market Value & 22,467 & 6,937 & 1,546 & 17,432 & 6,488 & $8,322 * * *$ & $1,641 * * *$ & 19,949 & 6,774 & 7,176 & $1,731 * * *$ & 17,074 \\
\hline Revenue & 22,467 & 5,272 & 1,266 & 12,291 & 6,488 & $6,254 * * *$ & $1,019 * * *$ & 14,970 & 6,774 & $6,037 * * *$ & $1,606 * * *$ & 13,293 \\
\hline$R \& D$ & 22,467 & 0.035 & 0.000 & 0.063 & 6,488 & $0.063 * * *$ & $0.031 * * *$ & 0.080 & 6,774 & $0.032 * * *$ & $0.000 * * *$ & 0.060 \\
\hline$C A P X$ & 22,467 & 0.106 & 0.036 & 0.249 & 6,488 & $0.078 * * *$ & $0.032 * * *$ & 0.172 & 6,774 & $0.114 * * *$ & $0.047 * * *$ & 0.233 \\
\hline Adjusted ROA & 22,467 & 0.165 & 0.139 & 0.209 & 6,488 & 0.164 & $0.154 * * *$ & 0.188 & 6,774 & 0.165 & 0.139 & 0.208 \\
\hline Free Cash Flow & 22,467 & 0.129 & 0.107 & 0.212 & 6,488 & $0.099 * * *$ & $0.097 * * *$ & 0.197 & 6,774 & 0.131 & $0.108 *$ & 0.210 \\
\hline$M \& A$ & 22,467 & 0.034 & 0.000 & 0.079 & 6,488 & 0.034 & $0.000 * * *$ & 0.078 & 6,774 & 0.034 & 0.000 & 0.080 \\
\hline Book-to-Market & 22,467 & 0.548 & 0.458 & 0.470 & 6,488 & $0.504 * * *$ & $0.415 * * *$ & 0.445 & 6,774 & $0.568 * * *$ & $0.488 * * *$ & 0.483 \\
\hline Leverage & 22,467 & 0.219 & 0.190 & 0.197 & 6,488 & $0.189 * * *$ & $0.152 * * *$ & 0.190 & 6,774 & $0.250 * * *$ & $0.224 * * *$ & 0.199 \\
\hline Stock Issuance & 22,467 & 0.425 & 0.000 & 0.494 & 6,488 & $0.434 *$ & 0.000 & 0.496 & 6,774 & $0.458 * * *$ & 0.000 & 0.498 \\
\hline Segments & 22,467 & 3.362 & 3.000 & 2.423 & 6,488 & 3.400 & 3.000 & 2.525 & 6,774 & $3.588 * * *$ & $3.000 * * *$ & 2.505 \\
\hline $10-K$ Length & 22,467 & 1,482 & 1,409 & 538 & 6,488 & $1,625 * * *$ & $1,525 * * *$ & 555 & 6,774 & $1,673 * * *$ & $1,601 * * *$ & 542 \\
\hline R\&D Disclosure & 22,467 & 13.349 & 5.000 & 21.605 & 6,488 & $27.147 * * *$ & $19.000 * * *$ & 29.644 & 6,774 & $13.869 * *$ & 4.000 & 22.377 \\
\hline CAPX Disclosure & 22,467 & 24.838 & 22.000 & 15.671 & 6,488 & 24.694 & 21.000 & 15.121 & 6,774 & $39.578 * * *$ & $37.000 * * *$ & 16.067 \\
\hline Overconfident-Opt & 22,467 & 0.351 & 0.000 & 0.477 & 6,488 & $0.377 * * *$ & 0.000 & 0.485 & 6,774 & $0.335 * * *$ & 0.000 & 0.472 \\
\hline Overconfident-SZ & 22,467 & 0.355 & 0.000 & 0.479 & 6,488 & $0.379 * * *$ & 0.000 & 0.485 & 6,774 & $0.398 * * *$ & 0.000 & 0.490 \\
\hline
\end{tabular}


Table 2 provides correlations for firm characteristics. R\&D and CAPX (and R\&D disclosure and CAPX disclosure) are negatively correlated implying that managers may view them as substitutes for growing the firm. While investment levels and disclosure are positively correlated for both R\&D and CAPX, the correlation is markedly larger for R\&D than CAPX (Spearman correlations of 0.850 and 0.415 respectively). This is potentially due to there being more information uncertainty surrounding $\mathrm{R} \& \mathrm{D}$ investments, thus requiring more disclosure.

\section{IV.III. SETTING VALIDATION}

I begin my analysis by validating my assumption in Section 3 that narrative R\&D disclosures have greater proprietary costs than narrative CAPX disclosures. In order to examine the relative proprietary costs of R\&D and CAPX disclosures, I first examine how disclosure varies as the likelihood that a firm's rivals appropriate information differs. If managers perceive investment disclosures to have proprietary costs, then they will disclose less when the firm is in an environment where disclosing proprietary information is expected to be costlier (e.g., when rivals are more likely to take advantage of disclosed proprietary information).

To proxy for proprietary costs arising from the firm's environment, I examine the level of competition that the firm faces, as prior literature argues that more significant competition leads to greater proprietary costs due to greater information spillovers (e.g., Huang et al. [2017]). If proprietary costs deter investment disclosures, then firms with greater competition should have fewer investment disclosures. To test this, I use a firm-specific proxy for competition since identifying environments with proprietary costs more broadly is difficult in this setting for two reasons. First, a notable amount of prior literature has used the presence or extent of R\&D as a 


\section{TABLE 2}

\section{Correlations}

This table reports correlations between the firm characteristics and discretionary disclosure variables reported in Table 1. Numbers above (below) the diagonal are Spearman (Pearson) correlations. Correlations significant at the 1\% level are in bold.

\begin{tabular}{|c|c|c|c|c|c|c|c|c|c|c|c|c|c|c|c|}
\hline & 1. & 2. & 3. & 4. & 5. & 6. & 7. & 8. & 9. & 10. & 11. & 12. & 13. & 14. & 15. \\
\hline Adjusted Assets & 1.000 & 0.830 & $\mathbf{0 . 8 3 7}$ & -0.169 & -0.232 & -0.198 & -0.113 & 0.093 & 0.011 & 0.310 & -0.194 & 0.359 & 0.395 & -0.125 & 0.042 \\
\hline Market Value & 0.509 & 1.000 & 0.772 & -0.068 & 0.012 & 0.185 & 0.239 & 0.106 & -0.304 & 0.154 & -0.198 & 0.250 & 0.266 & -0.035 & 0.070 \\
\hline Revenue & 0.506 & 0.788 & 1.000 & -0.238 & 0.119 & 0.019 & 0.153 & 0.110 & -0.037 & 0.244 & -0.233 & 0.377 & 0.263 & -0.194 & 0.195 \\
\hline$R \& D$ & -0.088 & -0.128 & -0.316 & 1.000 & -0.062 & 0.220 & -0.095 & 0.059 & -0.245 & -0.244 & 0.030 & -0.061 & 0.007 & 0.850 & -0.053 \\
\hline$C A P X$ & -0.083 & 0.013 & -0.018 & -0.125 & 1.000 & 0.548 & 0.599 & -0.012 & -0.097 & 0.031 & -0.011 & -0.026 & -0.126 & -0.089 & 0.415 \\
\hline Adjusted ROA & -0.086 & 0.200 & 0.046 & 0.063 & 0.573 & 1.000 & 0.885 & 0.015 & -0.342 & -0.195 & -0.076 & -0.124 & -0.170 & 0.153 & 0.133 \\
\hline Free Cash Flow & -0.058 & 0.231 & 0.145 & -0.249 & 0.589 & 0.931 & 1.000 & 0.028 & -0.293 & -0.095 & -0.102 & -0.048 & -0.204 & -0.100 & 0.182 \\
\hline$M \& A$ & -0.062 & -0.003 & -0.027 & -0.019 & 0.007 & 0.015 & 0.020 & 1.000 & -0.034 & 0.054 & -0.014 & 0.129 & $\mathbf{0 . 0 3 7}$ & 0.110 & -0.001 \\
\hline 9. Book-to-Market & 0.061 & -0.281 & -0.038 & -0.166 & 0.076 & -0.184 & -0.126 & -0.032 & 1.000 & -0.031 & 0.039 & 0.086 & 0.079 & -0.219 & 0.031 \\
\hline 10. Leverage & 0.020 & 0.084 & 0.158 & -0.207 & 0.066 & -0.120 & -0.056 & 0.090 & -0.081 & 1.000 & 0.017 & 0.140 & 0.206 & -0.226 & 0.232 \\
\hline 11. Stock Issuance & -0.125 & -0.199 & -0.233 & 0.054 & 0.042 & -0.044 & -0.058 & 0.064 & 0.002 & 0.024 & 1.000 & -0.069 & -0.028 & 0.023 & 0.038 \\
\hline 12. Segments & 0.279 & 0.271 & 0.377 & -0.165 & -0.104 & -0.106 & -0.049 & 0.017 & 0.052 & 0.083 & -0.063 & 1.000 & 0.214 & -0.014 & 0.108 \\
\hline 13. $10-K$ Length & 0.402 & 0.287 & 0.293 & -0.007 & -0.009 & -0.120 & -0.123 & 0.006 & 0.107 & 0.161 & -0.035 & 0.239 & 1.000 & 0.111 & 0.225 \\
\hline 14. R\&D Disclosure & -0.023 & -0.018 & -0.236 & 0.681 & -0.144 & 0.014 & -0.204 & 0.026 & -0.154 & -0.141 & 0.052 & -0.112 & 0.150 & 1.000 & -0.015 \\
\hline 15. CAPX Disclosure & -0.080 & 0.065 & 0.185 & -0.128 & 0.169 & 0.084 & 0.119 & 0.023 & 0.029 & 0.192 & $\mathbf{0 . 0 3 7}$ & 0.101 & 0.232 & -0.066 & 1.000 \\
\hline
\end{tabular}


proxy for the firm operating in an environment with high proprietary costs (e.g., Albring, Banyi, Dhaliwal, and Periera [2016]). This is problematic in this setting as the extent of R\&D is likely to directly influence the amount of investment disclosure. Second, industry-based measures of proprietary costs are also common (e.g., Huang et al. [2017]). However, for reasons unrelated to proprietary costs (technology or industry biases in word lists), the extent of investment disclosure is likely to be markedly different between industries, making industry-based measures for proprietary costs inappropriate in this setting.

To address these issues, I use a text-based measure of product market competition developed by Hoberg and Phillips (2016) to capture the level of competition on a firm-year basis. The specific measure (Competition) is a modified Herfindahl-Hirschman Index (HHI) that is computed for each firm by examining the firm's product market peers. Product market peers are based on the firm's Text-Based Network Industry Classification (TNIC) grouping derived by Hoberg and Phillips (2016) by examining the similarity of firms' 10-K product descriptions. The measure varies by firm and year as the product descriptions of a firm and its peers change, allowing for examination of how investment disclosure is associated with firm and time specific competition. I multiple the HHI value for the firm's TNIC by negative one so that it varies from -1 to 0 such that higher values indicate higher levels of product market competition. I run the following OLS regressions, with and without the interaction terms, where $R \& D_{-}$Disc and CAPX_Disc are equal to the natural log of one plus either the number of R\&D or CAPX sentences in the $10-\mathrm{K}^{13}$ If the presence of firm-level proprietary costs results in decreased discretionary disclosure per dollar of investment then $\beta_{3}\left(\gamma_{3}\right)$ will be less than zero.

${ }^{13}$ Due to the count nature of the dependent disclosure variables, in untabulated robustness tests I rerun this and the remaining OLS regressions with disclosure as a dependent variable using Poisson regressions and find that the results remain significant. 


$$
\begin{gathered}
R \& D_{-} \text {Disc }_{i, t}=\beta_{0}+\beta_{1} \text { Competition }_{i, t}+\beta_{2} R \& D_{i, t} \\
+\beta_{3} \text { Competition }^{2} R \& D_{i, t}+\text { Controls } \\
\text { CAPX_Disc } C_{i, t}=\gamma_{0}+\gamma_{1} \text { Competition }_{i, t}+\gamma_{2} \text { CAPX }_{i, t} \\
+\gamma_{3} \text { Competition } * \text { CAPX }_{i, t}+\text { Controls }
\end{gathered}
$$

Control variables include factors potentially related to investment disclosure. I control for firm size (natural log of market value), complexity (number of business and operating segments), financing decisions (leverage and stock issuance), earnings (net income plus R\&D and depreciation scaled by adjusted assets), cash flow, M\&A activity (cash M\&A value scaled by adjusted assets), and the book-to-market ratio as prior literature suggests that they may be associated with incentives or disclosure strategy (e.g., Hope, Hu, and Lu [2016]; Huang et al. [2017]). Finally, similar to Merkley (2014), I control for the length of the annual report by including the natural $\log$ of the total number of sentences. Further information on variable definitions can be found in Appendix A. I include industry and year fixed effects to control for time and industry trends in disclosure.

Table 3 presents the results of the above regressions. Panel A reports the distribution of the competition proxy while Panel B reports the results of equations (1) and (2). The coefficient on the interaction between Competition and $R \& D$ in Column 2 is significantly negative, indicating the firms with higher levels of competition disclose less about R\&D per dollar of R\&D investment. In contrast to Column 2, Column 4 suggests a positive association between Competition and CAPX disclosure. Specifically, firms with high levels of product market competition disclose more about CAPX activities, regardless of their level of CAPX. The results indicate that R\&D disclosure are more responsive to competition then CAPX disclosures, and 
TABLE 3

\section{Competitive Environment and Proprietary Disclosure Costs}

This table reports the results from running OLS regressions of discretionary investment disclosure on firm competition (proxy for firm-specific proprietary costs). Panel A reports descriptives for the competition measure. Panel B Columns 1 and 2 (3 and 4) reports the results for R\&D (CAPX) disclosure. Significance levels of 10\%, 5\%, and 1\%, are represented by *, **, and $* * *$ respectively. Standard errors are clustered by firm. Variable definitions are in Appendix A.

\begin{tabular}{l|ccccc} 
Panel A & Mean & $\mathbf{2 5}^{\text {th }}$ \% & Median & $\mathbf{7 5}^{\text {th }}$ \% & SD \\
\hline Competition & -0.220 & -0.280 & -0.153 & -0.091 & 0.193 \\
\hline
\end{tabular}

\begin{tabular}{|c|c|c|c|c|}
\hline \multirow[t]{2}{*}{ Dependent Variable: } & \multicolumn{2}{|c|}{ R\&D Disclosure } & \multicolumn{2}{|c|}{ CAPX Disclosure } \\
\hline & $(1)$ & $(2)$ & $(3)$ & $(4)$ \\
\hline Competition & -0.038 & 0.109 & $0.080 * *$ & $0.110 * *$ \\
\hline$R \& D$ & $7.664 * * *$ & $6.689 * * *$ & $-0.912 * * *$ & $-0.926 * * *$ \\
\hline$C A P X$ & $-0.386 * * *$ & $-0.387 * * *$ & $0.080 * *$ & 0.032 \\
\hline Competition $* R \& D$ & & $-5.337 * * *$ & & \\
\hline Competition $*$ CAPX & & & & -0.395 \\
\hline Market Value & $0.026 * * *$ & $0.027 * * *$ & $-0.012 *$ & $-0.012 *$ \\
\hline Adj_ROA & $-0.546 * * *$ & $-0.519 * * *$ & 0.034 & 0.034 \\
\hline Free Cash Flow & $0.580 * * *$ & $0.543 * * *$ & $0.150 *$ & 0.144 \\
\hline$M \& A$ & $0.280 * * *$ & $0.285^{* * *}$ & -0.030 & -0.030 \\
\hline Book-to-Market & $-0.117 * * *$ & $-0.115^{* * *}$ & -0.007 & -0.008 \\
\hline Leverage & $-0.641 * * *$ & $-0.635 * * *$ & $0.199 * * *$ & $0.198 * * *$ \\
\hline Stock Issuance & 0.004 & 0.003 & $0.066^{* * *}$ & $0.066^{* * *}$ \\
\hline Segments & -0.002 & -0.003 & 0.002 & 0.002 \\
\hline 10-K Length & $0.635 * * *$ & $0.634 * * *$ & $0.708 * * *$ & $0.709 * * *$ \\
\hline Year FE & Yes & Yes & Yes & Yes \\
\hline Industry FE & Yes & Yes & Yes & Yes \\
\hline$R$-Squared & $71.7 \%$ & $71.8 \%$ & $47.3 \%$ & $47.2 \%$ \\
\hline Observations & 22,344 & 22,344 & 22,344 & 22,344 \\
\hline
\end{tabular}


that firms in more competitive environments disclose less about R\&D per dollar of investment than firms in less competitive environments.

Next, I examine how observed discretionary investment disclosure is associated with the future return on the underlying investment. If investment disclosures convey proprietary information to rival firms that can be used to harm the disclosing firm, there will be a lower return on investment for firms with more investment disclosures. This would provide further validation that $\mathrm{R} \& \mathrm{D}$ disclosures have, on average, higher proprietary disclosure costs, leading to a more significant decline in the return on R\&D than the effect of CAPX disclosures.

To test this, I use a model similar to that used by Curtis et al. (2017) and regress the sum of future net income (adjusted for depreciation and R\&D) over the next three or five years scaled by adjusted assets $\left(A d j \_R O A\right)$ on current investment levels and indicators if the firm is in the highest tercile of R\&D or CAPX disclosure in their year and industry. ${ }^{14}$ As suggested by prior literature (Curtis et al. [2017]), I include controls for current adjusted ROA, adjusted ROA growth, the book-to-market ratio, and industry and year fixed effects. ${ }^{15}$ If high R\&D (CAPX) disclosure is associated with a lower return on R\&D (CAPX) over the next three or five years, $\beta_{3}$ $\left(\beta_{6}\right)$ will be negative.

$$
\begin{aligned}
& A d j \_R O A_{i, t+1, t+3}=\beta_{0}+\beta_{1} R \& D_{i, t}+\beta_{2} H i g h \_R \& D \_D i s c l o s e r_{i, t} \\
& +\beta_{3} R \& D * H i g h_{-} R \& D \_ \text {Discloser }{ }_{i, t}+\beta_{4} C A P X_{i, t}+\beta_{5} H_{i g h} \text { CAPX_Discloser }{ }_{i, t} \\
& +\beta_{6} C A P X * H i g h_{-} C A P X_{-} \text {Discloser } r_{i, t}+\text { Controls }+\varepsilon
\end{aligned}
$$

Table 4 reports the results from regressing future earnings on investment levels and investment disclosure. Columns 1 and 2 report the results of looking at earnings for the

\footnotetext{
${ }^{14}$ In untabulated robustness tests I classify firms as being a high disclosing firm if they are in the top half instead of tercile and the results remain substantially unchanged.

15 Unlike prior literature, I do not adjust earnings by advertising expense or include it as an independent variable. I do this because reporting advertising expense is often a disclosure choice and may depend on proprietary costs (see Simpson [2008] for further discussion).
} 
subsequent three years while Columns 3 and 4 report the results of looking at earnings for the subsequent five years. The results indicate that firms with high $R \& D$ disclosures have $R \& D$ investments that are associated with approximately $25 \%$ lower future earnings than the R\&D investments of firms without high $R \& D$ disclosures. ${ }^{16}$ Further, the results do not provide consistent statistical evidence about whether firms with high CAPX disclosures have CAPX investments that are associated with lower future earnings. Taken together, the results in this section provide support for the view that R\&D disclosure have greater proprietary disclosure costs than CAPX disclosure.

${ }^{16}$ Column 2: $(2.136-0.528) / 2.136=0.75$. Column $4:(4.634-1.449) / 4.634=0.69$ 
TABLE 4

\section{Return on Investment Analysis}

This table reports the results from running OLS regressions of adjusted future earnings on investment levels and indicators if the firm is a high investment disclosing firm. Significance levels of $10 \%, 5 \%$, and $1 \%$, are represented by $*, * *$, and $* * *$ respectively. Standard errors are clustered by firm. Variable definitions are in Appendix A.

\begin{tabular}{|c|c|c|c|c|}
\hline \multirow[t]{2}{*}{ Dependent Variable: } & \multicolumn{2}{|c|}{ Adjusted 3-Year Earnings } & \multicolumn{2}{|c|}{ Adjusted 5-Year Earnings } \\
\hline & (1) & (2) & (3) & $(4)$ \\
\hline$R \& D$ & $3.379 * * *$ & $2.136 * * *$ & $6.701 * * *$ & $4.634 * * *$ \\
\hline High R\&D Disclosure & $0.026^{*}$ & -0.011 & 0.047 & -0.008 \\
\hline$R \& D^{*}$ High $R \& D$ Disclosure & $-1.232 * * *$ & $-0.528 * *$ & $-2.615 * * *$ & $-1.449 * *$ \\
\hline$C A P X$ & $1.636 * * *$ & $0.817 * * *$ & $2.982 * * *$ & $1.639 * * *$ \\
\hline High CAPX Disclosure & -0.009 & 0.014 & $-0.062 *$ & -0.017 \\
\hline CAPX*High CAPX Disclosure & 0.007 & -0.039 & 0.420 & 0.322 \\
\hline Adjusted ROA & & $1.754 * * *$ & & $2.911 * * *$ \\
\hline Adjusted ROA Growth & & $-0.356 * * *$ & & -0.657 \\
\hline Book-to-Market & & $-0.215^{* * *}$ & & $-0.361 * * *$ \\
\hline Year FE & Yes & Yes & Yes & Yes \\
\hline Industry FE & Yes & Yes & Yes & Yes \\
\hline$R$-Squared & $44.6 \%$ & $60.4 \%$ & $46.9 \%$ & $59.1 \%$ \\
\hline Observations & 17,712 & 17,712 & 13,768 & 13,768 \\
\hline
\end{tabular}




\section{CHAPTER V}

\section{HYPOTHESIS TESTING}

\section{V.I. RESEARCH DESIGN}

To test my main hypothesis, I examine the association between the presence of an overconfident CEO and the firm's discretionary disclosure of both R\&D and CAPX related information. I develop two measures of CEO overconfidence based on prior work in accounting and finance and motivated by the psychology literature. The first measure of overconfidence (Overconfident-Opt) is based on a CEO's stock option holding behavior and follows Campbell, Gallmeyer, Johnson, Rutherford, and Stanley (2011). The intuition behind this measure is based on the view that it is optimal for a CEO to exercise stock options early if they are sufficiently in the money (Hall and Murphy [2002]). If a CEO decides to routinely hold fully vested high inthe-money stock options, it is likely that the CEO has overoptimistic beliefs about either the firm's future returns or underestimates the variability of future returns. ${ }^{17}$

Following Campbell et al. (2011) and Hribar and Yang (2016), I use stock option compensation details from ExecuComp to compute the average moneyness of stock options at yearend. To do this, I first estimate the realizable value per held option as the total realizable value of exercisable options divided by the number of exercisable options. Next, I estimate the average exercise price as the stock price at yearend less the average realizable value per exercisable option. Finally, the average moneyness of held options for the year is computed as the realizable value per held option divided by the average exercise price. I classify a CEO as

\footnotetext{
${ }^{17}$ Malmendier and Tate $(2008,2015)$ provide further discussion and validation of this measure.
} 
being overconfident if the CEO holds exercisable options with average moneyness of $100 \%$ at least twice during the CEO's tenure, starting with the first year the CEO exhibits the behavior. ${ }^{18}$

The second measure of overconfidence (Overconfident-SZ) is based on firm-specific decisions and is motivated by Schrand and Zechman (2012). This measure is based on the assumption that if a CEO is overconfident, the CEO is likely to be consistently overconfident when making decisions across different firm contexts, and evidence should be observable in a variety of firm decisions. I follow the process outlined in Kim et al. (2016) and identify a CEO as being overconfident the first time the firm satisfies three of the following five criteria during the CEO's tenure: (1) excess investment (measured as the residual from regressing asset growth on sales growth) is in the top quartile of firms in the industry-year; (2) net dollars of acquisitions (from the statement of cash flows) are in the top quartile of firms in the industry-year; (3) the debt-to-equity ratio is in the top quartile of firms in the industry-year; (4) the firm utilizes either convertible debt or preferred stock; and (5) the firm paid no dividends during the year. ${ }^{19}$

Due to data limitations, overconfidence variables are based on executive and firm behavior during fiscal years. However, the $10-\mathrm{K}$ is not filed until at least two months after the

${ }^{18}$ While some prior literature (e.g., Malmendier and Tate [2005, 2008]) uses $67 \%$ as the cutoff for overconfidence, I follow Campbell et al. (2011) and use the 100\% cutoff for two reasons. First, the ExecuComp data is not as detailed as the data initially used by Malmendier and Tate [2005] to motivate the $67 \%$ cutoff, so I use $100 \%$ to limit the number of CEOs incorrectly identified as being overconfident. Second, to the extent that the $67 \%$ cutoff correctly identifies CEOs as being overconfident, using a $100 \%$ cutoff identifies CEOs who are even more overconfident. If the threshold is altered to $67 \%(133 \%)$, the results are statistically consistent but with slightly lower (higher) coefficients.

${ }^{19}$ Excess investment may be systematically correlated with the type of investments that the firm pursues since R\&D and CAPX impact asset growth differently at the time of investment. To make sure that this is not resulting in spurious results, I run robustness tests excluding the excess investment requirement and instead requiring that two of the remaining four conditions be satisfied and the results remain consistent. 
end of the fiscal year, during which CEO turnover may occur. To address this issue, I treat firms with CEO turnover in the two months after the fiscal year as having a non-overconfident CEO. ${ }^{20}$

The two proxies for overconfidence approach identifying overconfident CEOs from different perspectives based on either looking at decisions surrounding the CEO's personal wealth or firm decisions made under the guidance of the CEO. Results that are consistent across both measures can provide validation that they are not due to idiosyncrasies in either CEO option exercise behavior or firm decisions. In untabulated robustness analysis, I develop two additional proxies which classify a CEO as being overconfident if both or either of the two proxies outlined above identify the CEO as being overconfident. The results remain statistically consistent but with slightly higher (lower) coefficients when both (either) proxies identify the CEO as being overconfident. $^{21}$

I run the following regressions where Overconfident equals one when the firm has a CEO identified as being overconfident. If overconfident CEOs disclose more about R\&D, but not more about CAPX, than their non-overconfident counterparts, $\beta_{1}$ will be greater than $\gamma_{1}$. I include the same vector of control variables used in equation (1). ${ }^{22}$

$$
\begin{gathered}
R \& D_{-} \text {Disc }_{i, t}=\beta_{0}+\beta_{1} \text { Overconfident }_{i, t}+\beta_{2} R \& D_{i, t}+\text { Controls } \\
\text { CAPX_Disc } \text { C }_{i, t}=\gamma_{0}+\gamma_{1} \text { Overconfident }_{i, t}+\gamma_{2} \text { CAPX }_{i, t}+\text { Controls }
\end{gathered}
$$

${ }^{20}$ The results remain consistent if I instead exclude the approximately 600 observations with CEO turnover during that time period.

${ }^{21}$ In further untabulated analysis I randomly assign $35 \%$ of CEOs as being placebo overconfident and rerun the main tests. The results indicate that the presence of a placebo overconfident CEO is not associated with either R\&D or CAPX disclosure.

${ }^{22}$ One concern with the regression model is the assumption that the relation between investment and investment disclosure is the same for firms with and without an overconfident CEO. In untabulated robustness analysis I include interactions between Overconfident and $R \& D$ (or $C A P X$ ) and find that the coefficients on Overconfident remain substantially unchanged and the interactions are insignificant. 


\section{V.II. RESULTS}

Table 5 Panel A reports the number of observations per year that are classified as having an overconfident CEO for both overconfidence proxies. Approximately $35 \%$ of observations have an overconfident CEO identified by either the option-based proxy or the SZ proxy. Panel B reports firm characteristics split on whether the firm has an overconfident CEO. Firms with overconfident CEOs engage in more M\&A activities, have more investments in $R \& D$, and disclose more about R\&D.

I begin by regressing the amount of discretionary disclosure on an indicator if the CEO is classified as being overconfident and control variables. Table 6 Panel A reports the results for the option proxy while Panel B reports the results for the SZ proxy. The results indicate that firms with overconfident CEOs have approximately 9\% more R\&D disclosure, and no significant difference in CAPX disclosure, when compared to firms without an overconfident CEO. ${ }^{23}$

Next, I use a Chi-Squared test to examine whether the coefficient on Overconfident for R\&D disclosure is significantly larger than for CAPX disclosure. The Chi-Squared test indicates that for both panels the effect of having an overconfident CEO is significantly greater for R\&D disclosure than for CAPX disclosure.

The industry that a firm is operating in is likely to have a notable effect on the majority of the control variables as well as the amount of investment disclosure. To ensure that the results are not sensitive to industry specific biases in the control variables that are not captured by industry fixed effects, I adjust all of the variables for industry norms by subtracting the median

${ }^{23}$ Using an approximation for interpreting the effect of Overconfident on R\&D disclosure in Column 1 Panel A (B) results in an increase in disclosure of $\mathrm{e}^{0.082}-1=8.5 \%\left(\mathrm{e}^{0.073}-1=7.6 \%\right)$ for firms with an overconfident CEO. The results are quantitatively similar when looking at the effect for the mean sample firm. 
TABLE 5

\section{Overconfidence Descriptives}

Panel A reports the number of overconfident observations per year. Panel B reports the mean and median of firm characteristics for the full sample and for firms with an overconfident CEO as identified by both overconfidence proxies. Adjusted assets, market value, revenue, and disclosure variables are reported as the unlogged amount for descriptive purposes only. *, **, and $* * *$ represent significant differences at the $10 \%, 5 \%$, and $1 \%$ level between NonOverconfident and Overconfident observations in means (medians) from a two-sided t-test (Wilcoxon rank-sum test). For binary variables, significance in means comes from a $\chi^{2}$ test.

\begin{tabular}{|c|c|c|c|c|c|}
\hline \multirow{3}{*}{$\begin{array}{l}\text { Panel A } \\
\text { Year }\end{array}$} & \multicolumn{5}{|c|}{ Distribution of Overconfident CEOs } \\
\hline & \multirow{2}{*}{ Full Sample } & \multicolumn{2}{|c|}{ Overconfident-Opt } & \multicolumn{2}{|c|}{ Overconfident-SZ } \\
\hline & & \# & $\%$ & \# & $\%$ \\
\hline 2001 & 965 & 346 & $35.9 \%$ & 315 & $32.6 \%$ \\
\hline 2002 & 1,428 & 469 & $32.8 \%$ & 515 & $36.1 \%$ \\
\hline 2003 & 1,458 & 539 & $37.0 \%$ & 565 & $38.8 \%$ \\
\hline 2004 & 1,435 & 552 & $38.5 \%$ & 535 & $37.3 \%$ \\
\hline 2005 & 1,356 & 543 & $40.0 \%$ & 503 & $37.1 \%$ \\
\hline 2006 & 1,458 & 577 & $39.6 \%$ & 521 & $35.7 \%$ \\
\hline 2007 & 1,663 & 597 & $35.9 \%$ & 544 & $32.7 \%$ \\
\hline 2008 & 1,644 & 547 & $33.3 \%$ & 577 & $35.1 \%$ \\
\hline 2009 & 1,628 & 535 & $32.9 \%$ & 579 & $35.6 \%$ \\
\hline 2010 & 1,618 & 527 & $32.6 \%$ & 593 & $36.7 \%$ \\
\hline 2011 & 1,593 & 519 & $32.6 \%$ & 576 & $36.2 \%$ \\
\hline 2012 & 1,565 & 513 & $32.8 \%$ & 553 & $35.3 \%$ \\
\hline 2013 & 1,561 & 557 & $35.7 \%$ & 555 & $35.6 \%$ \\
\hline 2014 & 1,569 & 564 & $35.9 \%$ & 538 & $34.3 \%$ \\
\hline 2015 & 1,526 & 500 & $32.8 \%$ & 510 & $33.4 \%$ \\
\hline Total & 22,467 & 7,885 & $35.1 \%$ & 7,979 & $35.5 \%$ \\
\hline
\end{tabular}

\begin{tabular}{|c|c|c|c|c|c|c|}
\hline $\begin{array}{l}\text { Panel B: } \\
\text { Firm Characteristics }\end{array}$ & & ample & Overcon & ident-Opt & Overcol & ident-SZ \\
\hline & Mean & Median & Mean & Median & Mean & Median \\
\hline Adjusted Assets & 6,339 & 1,133 & $4,899 * * *$ & $1,027 * * *$ & 6,217 & $1,285 * * *$ \\
\hline Market Value & 6,937 & 1,546 & 6,693 & $1,806 * * *$ & $6,136^{* * *}$ & 1,530 \\
\hline Revenue & 5,272 & 1,266 & $4,631 * * *$ & $1,187 * * *$ & $4,900 * * *$ & $1,343 * * *$ \\
\hline$R \& D$ & 0.035 & 0.000 & $0.038 * * *$ & $0.000 * * *$ & $0.040 * * *$ & $0.000 * * *$ \\
\hline$C A P X$ & 0.106 & 0.036 & $0.120 * * *$ & $0.038 * * *$ & $0.088 * * *$ & $0.032 * * *$ \\
\hline Adjusted ROA & 0.165 & 0.139 & $0.196 * * *$ & $0.164 * * *$ & $0.142 * * *$ & $0.123 * * *$ \\
\hline Free Cash Flow & 0.129 & 0.107 & $0.157 * * *$ & $0.123 * * *$ & $0.101 * * *$ & $0.092 * * *$ \\
\hline$M \& A$ & 0.034 & 0.000 & $0.039 * * *$ & $0.000 * * *$ & $0.055 * * *$ & $0.006 * * *$ \\
\hline Book-to-Market & 0.549 & 0.458 & $0.473 * * *$ & $0.387 * * *$ & $0.572 * * *$ & $0.484 * * *$ \\
\hline Leverage & 0.219 & 0.190 & $0.200 * * *$ & $0.166^{* * *}$ & $0.271 * * *$ & $0.254 * * *$ \\
\hline Stock Issuance & 0.425 & 0.000 & $0.439 * * *$ & 0.000 & $0.462 * * *$ & 0.000 \\
\hline Segments & 3.362 & 3.000 & $3.085 * * *$ & $3.000 * * *$ & $3.324 *$ & 3.000 \\
\hline 10-K Length & 1,482 & 1,409 & $1,449 * * *$ & $1,382 * * *$ & $1,571 * * *$ & $1,494 * * *$ \\
\hline R\&D Disclosure & 13.349 & 5.000 & $15.162 * *$ & $5.000 * * *$ & $16.887 * * *$ & $6.000 * * *$ \\
\hline CAPX Disclosure & 24.838 & 22.000 & $24.158 * * *$ & $20.000 * * *$ & $25.287 * * *$ & $22.000 * * *$ \\
\hline
\end{tabular}


TABLE 6

Investment Disclosure

This table reports the results from running OLS regressions of the amount of investment disclosure on the presence of an overconfident CEO. Panel A reports the results using the optionbased proxy for overconfidence while Panel B reports the results using the Schrand and Zechman proxy. Significance levels of $10 \%, 5 \%$, and $1 \%$, are represented by $* * *$, and $* * *$ respectively. Standard errors are clustered by firm. Variable definitions are in Appendix A.

\begin{tabular}{|c|c|c|}
\hline $\begin{array}{l}\text { Panel A: Overconfident-Opt } \\
\text { Dependent Variable: }\end{array}$ & $R \& D$ Disclosure (1) & CAPX Disclosure (2) \\
\hline Overconfident & $0.082 * * *$ & -0.010 \\
\hline$R \& D$ & $7.585 * * *$ & $-0.876^{* * *}$ \\
\hline$C A P X$ & $-0.387 * * *$ & $0.082 * *$ \\
\hline Market Value & $0.023 * *$ & -0.010 \\
\hline Adj_ROA & $-0.495 * * *$ & 0.038 \\
\hline Free Cash Flow & $0.519 * * *$ & $0.143 *$ \\
\hline$M \& A$ & $0.249 * * *$ & -0.030 \\
\hline Book-to-Market & $-0.112 * * *$ & -0.005 \\
\hline Leverage & $-0.628 * * *$ & $0.197 * * *$ \\
\hline Stock Issuance & 0.002 & $0.067^{* * *}$ \\
\hline Segments & -0.001 & 0.001 \\
\hline 10-K Length & $0.640 * * *$ & $0.711 * * *$ \\
\hline Year FE & Yes & Yes \\
\hline Industry FE & Yes & Yes \\
\hline$R$-Squared & $71.8 \%$ & $47.3 \%$ \\
\hline Observations & 22,467 & 22,467 \\
\hline$\chi^{2}$ Test: Overconfident (1) - (2) & $8.90 * * *$ & \\
\hline \multicolumn{3}{|l|}{ Panel B: Overconfident-SZ } \\
\hline Overconfident & $0.073 * * *$ & $-0.029 *$ \\
\hline$R \& D$ & $7.597 * * *$ & $-0.879 * * *$ \\
\hline$C A P X$ & $-0.381 * * *$ & $0.079 * *$ \\
\hline Market Value & $0.025^{* *}$ & -0.010 \\
\hline Adj_ROA & $-0.497 * * *$ & 0.039 \\
\hline Free Cash Flow & $0.533^{* * *}$ & 0.141 \\
\hline$M \& A$ & $0.205^{* *}$ & -0.004 \\
\hline Book-to-Market & $-0.126 * * *$ & -0.002 \\
\hline Leverage & $-0.686 * * *$ & $0.217 * * *$ \\
\hline Stock Issuance & 0.002 & $0.068 * * *$ \\
\hline Segments & -0.001 & 0.001 \\
\hline 10-K Length & $0.626^{* * *}$ & $0.715 * * *$ \\
\hline Year FE & Yes & Yes \\
\hline Industry FE & Yes & Yes \\
\hline$R$-Squared & $71.8 \%$ & $47.3 \%$ \\
\hline Observations & 22,467 & 22,467 \\
\hline$\chi^{2}$ Test: Overconfident (1) - (2) & $10.36^{* * *}$ & \\
\hline
\end{tabular}


industry-year value from each variable. Untabulated analysis indicates that the results are substantially unchanged for both R\&D and CAPX disclosures.

Firms with and without an overconfident CEO may be systematically different in a manner which may cause there to be differences in disclosure levels (i.e., the results may be due to a firm effect instead of an overconfidence effect). ${ }^{24}$ To help mitigate this concern, I utilize propensity score matching (PSM) techniques to identify a group of firms with similar observable characteristics and rerun the tests performed in Table 6 (see Appendix $\mathrm{C}$ for further discussion and PSM robustness analyses). I match (1-to-1) firms with an overconfident CEO to firms without an overconfident CEO on the propensity to have an overconfident CEO (using a caliper of 0.01 , see Appendix $\mathrm{C}$ for results from the first stage logit regression). Table 7 reports the second stage OLS results from running the regressions on the matched sample. All of the second stage tests have all 11 dependent variables being the same between firms with and without an overconfident CEO (p-value for difference in means $>0.01$ ), indicating that the matching process produces a comparable set of control firms. The results are similar (but with slightly smaller coefficients) to those in Table 6 , which is consistent with the results not being driven by systematic differences in observable firm characteristics between firms with and without an overconfident CEO.

Taken together, the above results provide support for my hypothesis that CEO overconfidence is associated with more disclosure of investment information with proprietary costs when compared to the disclosure of investment information with limited proprietary costs. The coefficients in Tables 6 and 7 also imply that firm characteristics affect discretionary R\&D

${ }^{24}$ For example, if the relation between $R \& D$ and $R \& D$ disclosure is not linear, then the fact that firms with overconfident CEOs have more R\&D may induce bias in the results due to functional form misspecification. 
TABLE 7

\section{Investment Disclosure - Propensity Score Matching}

This reports the results from running the second stage of the PSM models. Balanced covariates report the number of control variables where the $p$-value for the difference in means between firms with and without an overconfident CEO is $>0.01$. Significance levels of $10 \%, 5 \%$, and $1 \%$, are represented by $* * *$, and $* * *$ respectively. Standard errors are clustered by firm. Variable definitions are in Appendix A.

\begin{tabular}{|c|c|c|}
\hline $\begin{array}{l}\text { Panel A: Overconfident-Opt } \\
\text { Dependent Variable: }\end{array}$ & R\&D Disclosure (1) & CAPX Disclosure (2) \\
\hline Overconfident & $0.072 * * *$ & -0.010 \\
\hline$R \& D$ & $7.428 * * *$ & $-0.854 * * *$ \\
\hline$C A P X$ & $-0.417 * * *$ & 0.057 \\
\hline Market Value & $0.020 *$ & -0.002 \\
\hline Adj_ROA & $-0.688 * * *$ & 0.073 \\
\hline Free Cash Flow & $0.763 * * *$ & 0.146 \\
\hline$M \& A$ & $0.204 * *$ & -0.002 \\
\hline Book-to-Market & $-0.115^{* * *}$ & 0.015 \\
\hline Leverage & $-0.601 * * *$ & $0.173 * * *$ \\
\hline Stock Issuance & -0.002 & $0.060 * * *$ \\
\hline Segments & 0.001 & -0.002 \\
\hline 10-K Length & $0.667 * * *$ & $0.738 * * *$ \\
\hline Balanced Covariates & $11 / 11$ & $11 / 11$ \\
\hline Year FE & Yes & Yes \\
\hline Industry FE & Yes & Yes \\
\hline$R$-Squared & $72.7 \%$ & $47.7 \%$ \\
\hline Observations & 15,118 & 15,118 \\
\hline$\chi^{2}$ Test: Overconfident (1) - (2) & $6.84 * * *$ & \\
\hline \multicolumn{2}{|l|}{ Panel B: Overconfident-SZ } & CAPX Disclosure (2) \\
\hline Overconfident & $0.065^{* *}$ & -0.026 \\
\hline$R \& D$ & $7.296^{* * *}$ & $-0.823 * * *$ \\
\hline$C A P X$ & $-0.432 * * *$ & 0.104 \\
\hline Market Value & $0.029 * * *$ & -0.010 \\
\hline Adj_ROA & $-0.514 * * *$ & 0.144 \\
\hline Free Cash Flow & $0.529 * * *$ & 0.021 \\
\hline$M \& A$ & $0.267 * *$ & 0.017 \\
\hline Book-to-Market & $-0.105 * * *$ & 0.019 \\
\hline Leverage & $-0.674 * * *$ & $0.176^{* * *}$ \\
\hline Stock Issuance & 0.016 & $0.066 * * *$ \\
\hline Segments & -0.003 & 0.004 \\
\hline 10-K Length & $0.652 * * *$ & $0.701 * * *$ \\
\hline Balanced Covariates & $11 / 11$ & $11 / 11$ \\
\hline Year FE & Yes & Yes \\
\hline Industry FE & Yes & Yes \\
\hline$R$-Squared & $72.4 \%$ & $46.0 \%$ \\
\hline Observations & 12,508 & 12,508 \\
\hline$\chi^{2}$ Test: Overconfident (1) - (2) & $7.82 * * *$ & \\
\hline
\end{tabular}


and CAPX disclosures differently. For example, lower book-to-market ratios, more cash flow, and more M\&A activity are associated with greater amounts of R\&D disclosure while not being consistently associated with CAPX disclosure. The presence of stock issuance during the year is associated with higher amounts of CAPX disclosures without a comparable association with R\&D disclosures.

\section{V.III. ADDITIONAL ANALYSIS - DISCLOSURE CONTENT}

If overconfident CEOs perceive the proprietary costs of discretionary investment disclosure to be lower, then it is likely that the qualitative characteristics of their narrative investment disclosures will also be systematically different. Specifically, the increase in discretionary R\&D disclosure should stem from an increase in disclosures that are more proprietary in nature, and not from an increase in disclosures that do not convey proprietary information. To test this, I proxy for R\&D disclosures that are more proprietary in two ways.

First, investment disclosures that are more uncertain may have greater proprietary costs associated with their disclosure. This may be due to them contain information either about what the firm is considering doing but has not yet committed to do (i.e., commitment uncertainty) or about what the outcomes of the project are likely to be (i.e., outcome uncertainty). To the extent that uncertain disclosures reveal more information about future performance, operations, and strategic plans than non-uncertain disclosures, I expect uncertain disclosures to be more proprietary since they reveal information that can be extremely useful to rival firms (X. Li [2010]). To identify uncertain disclosures, I search each investment related sentence for the 
presence of uncertain words and classify a sentence as being uncertain if it has at least one uncertain word. $^{25}$

Second, information about what the firm has already done (historical investment disclosure) is likely to contain less proprietary than information about what the firm is currently doing or plans to do in the future (non-historical investment disclosure). This is due to the difference in the amount of time rivals can use and act upon the information in a manner that hurts the disclosing firm's competitive advantage. To the extent that information about current and future investments allows rivals more time to use the information, these disclosures are expected to have greater proprietary costs than historical information.

To identify historical investment disclosures, I utilize an algorithm that examines the verb tense of investment sentences. Importantly, this is different from the methods used by F. Li (2010) and Muslu, Radhakrishnan, Subramanyam, and Lim (2015) for identifying forwardlooking disclosures in two ways. First, both F. Li (2010) and Muslu et al. (2015) use a modified bag of words approach where a disclosure is identified as being forward-looking if one of either 17 (F. Li [2010]) or 365 (Muslu et al. [2015]) words or phrases are a part of the disclosure. Instead of developing a list of words and phrases that imply the disclosure is likely about historical information, I instead examine the verb tenses of the disclosures. This allows for potentially more accurate identification as it relies on the meaning and usage of the underlying words, and not just on the presence of specific words. ${ }^{26}$ Second, I parse disclosures into historical and non-historical disclosures which groups together forward-looking disclosures with

${ }^{25}$ The list of uncertain words comes from the 2016 Loughran-McDonald Master Dictionary.

${ }^{26}$ To validate my measure of past oriented information, I manually classify 250 random R\&D and CAPX related sentences and compare the results to that of the verb tense algorithm. There is $91 \%$ agreement between the algorithm and the hand classified sentences in identifying sentences with predominantly past oriented information. 
disclosures about current investments. This is important in this setting as disclosures about current investments likely convey substantially more proprietary information than disclosures about historical investments.

To identify verb tenses, I use the Stanford CoreNLP toolkit in Python to identify the partof-speech that each word in each investment related sentence performs. Next, I look for the presence of words acting as verbs and count the number of verbs according to their verb form. I classify a sentence as being historical if at least half of the verbs in a sentence are either in the past tense or past participle form.

I use similar regressions to that used to test the main hypothesis (equations 4 and 5), but first separate disclosure into uncertain and non-uncertain measures of disclosure to test whether overconfident CEOs are associated with differential amounts of uncertain and non-uncertain investment disclosures. For comparison purposes I also run the following analysis for CAPX disclosures.

$$
\begin{aligned}
& \text { Invest_Disc_Uncertain }_{i, t}=\alpha_{i}+\beta_{1} \text { Overconfident }_{i, t}+\beta_{2} \text { Invest }_{i, t}+\text { Controls } \\
& \text { Invest_Disc_NonUncertain }_{i, t}=\alpha_{i}+\gamma_{1} \text { Overconfident }_{i, t}+\gamma_{2} \text { Invest }_{i, t}+\text { Controls }
\end{aligned}
$$

If overconfident CEOs are associated with a greater increase in the disclosure of uncertain information than they are with the disclosure of non-uncertain information, then $\beta_{1}$ will be larger than $\gamma_{1}$. Invest_Disc_Uncertain (Invest_Disc_NonUncertain) is equal to the natural $\log$ of one plus the number of uncertain (non-uncertain) R\&D or CAPX sentences.

I next split disclosure into non-historical and historical measures of disclosure and perform similar analysis as above to test whether overconfident CEOs are associated with differential amounts of non-historical and historical investment disclosures. 


$$
\begin{gathered}
\text { Invest_Disc_NonHistorical }_{i, t}=\alpha_{i}+\beta_{1} \text { Overconfident }_{i, t}+\beta_{2} \text { Invest }_{i, t}+\text { Controls } \\
\text { Invest_Disc_Historical }_{i, t}=\alpha_{i}+\gamma_{1} \text { Overconfident }_{i, t}+\gamma_{2} \text { Invest }_{i, t}+\text { Controls }
\end{gathered}
$$

If overconfident CEOs are associated with a greater increase in the disclosure of nonhistorical information than they are with the disclosure of historical information, then $\beta_{1}$ will be larger than $\gamma_{1}$. Invest_Disc_NonHistorical (Invest_Disc_Historical) is equal to the natural log of one plus the number of uncertain (non-uncertain) R\&D or CAPX sentences. ${ }^{27}$

Table 8 Panel A reports the results for R\&D disclosure separated out by whether the disclosure is uncertain or non-uncertain using the option proxy for overconfidence. The results indicate that the presence of an overconfident CEO is associated with more of both uncertain and non-uncertain $\mathrm{R} \& \mathrm{D}$ disclosure, but the effect is marginally larger for uncertain $\mathrm{R} \& \mathrm{D}$ disclosure. Specifically, the Chi-Squared test indicates that the coefficient on Overconfident is larger for uncertain $R \& D$ disclosure than non-uncertain $R \& D$ disclosure but is only significant at the $10 \%$ level. Panel B reports the results using the SZ proxy and finds similar results, but the coefficients on Overconfident are not statistically different.

Table 9 reports the results for the association between having an overconfident CEO and the amount of investment disclosure separated out by whether the disclosure is primarily historical. Panel A (Panel B) report the results using the option proxy (SZ proxy). The results indicate that the presence of an overconfident CEO has a significantly larger effect on the amount of non-historical R\&D disclosure than it does on historical R\&D disclosure. Similar to the results in prior tables, the presence of an overconfident CEO is not consistently associated with the disclosure of CAPX information.

${ }^{27}$ In untabulated robustness I look at differences in the percent of investment sentences that are classified as being uncertain or non-historical. The results are consistent and show that the presence of an overconfident CEO is associated with a greater percentage of investment disclosures being classified as uncertain (option proxy only) and non-historical (both overconfidence proxies). 
TABLE 8

\section{Uncertain Investment Disclosure}

This table reports the results from running OLS regressions of the amount of investment disclosure, partitioned by whether the disclosure is uncertain, on the presence of an overconfident CEO. Panel A (B) reports the results for R\&D (CAPX) disclosure. Significance levels of $10 \%, 5 \%$, and $1 \%$, are represented by $*, * *$, and $* * *$ respectively. Standard errors are clustered by firm. Variable definitions are in Appendix A.

\begin{tabular}{l|cc|cc} 
Panel A: Overconfident-Opt & \multicolumn{2}{c|}{ R\&D Disclosure } & \multicolumn{2}{c}{ CAPX Disclosure } \\
Disclosure Type: & Uncertain & Non-Uncertain & Uncertain & Non-Uncertain \\
& $(1)$ & $(2)$ & $(3)$ & $(4)$ \\
\hline Overconfident & $0.089^{* * *}$ & $0.058^{* *}$ & 0.009 & -0.013 \\
R\&D & $6.247^{* * *}$ & $7.056^{* * *}$ & $-0.645^{* * *}$ & $-0.948^{* * * *}$ \\
CAPX & $-0.145^{* * *}$ & $-0.381^{* * *}$ & $0.109^{* *}$ & 0.057 \\
Market Value & 0.009 & $0.022^{* *}$ & $-0.023^{* * *}$ & -0.002 \\
Adj_ROA & $-0.278^{* * *}$ & $-0.453^{* * *}$ & -0.035 & 0.092 \\
Free Cash Flow & $0.275^{* * *}$ & $0.498^{* * *}$ & $0.245^{* *}$ & 0.069 \\
M\&A & $0.262^{* * *}$ & $0.182^{* *}$ & 0.097 & $-0.100^{*}$ \\
Book-to-Market & -0.031 & $-0.115^{* * *}$ & 0.025 & -0.010 \\
Leverage & $-0.352^{* * *}$ & $-0.551^{* * *}$ & $0.293^{* * *}$ & $0.146^{* * *}$ \\
Stock Issuance & 0.006 & 0.007 & $0.097 * * *$ & $0.050^{* * *}$ \\
Segments & $-0.015^{* * *}$ & 0.002 & $-0.010^{* *}$ & 0.006 \\
10-K Length & $0.443^{* * *}$ & $0.580^{* * *}$ & $0.693^{* * *}$ & $0.654^{* * *}$ \\
& & & & \\
Year FE & Yes & Yes & Yes & Yes \\
Industry FE & Yes & Yes & Yes & Yes \\
R-Squared & $68.1 \%$ & $70.2 \%$ & $37.8 \%$ & $42.4 \%$ \\
Observations & 22,467 & 22,467 & 22,467 & 22,467 \\
$\chi^{2}$ Test: Overconfident (1)-(2) & $2.57^{*}$ & & $(3)-(4): 1.57$ & \\
& & & & \\
\hline
\end{tabular}




\begin{tabular}{|c|c|c|c|c|}
\hline \multirow{2}{*}{$\begin{array}{l}\text { Panel B: Overconfident-SZ } \\
\text { Disclosure Type: }\end{array}$} & \multicolumn{2}{|c|}{ R\&D Disclosure } & \multicolumn{2}{|c|}{ CAPX Disclosure } \\
\hline & $\begin{array}{c}\text { Uncertain } \\
\text { (1) }\end{array}$ & $\begin{array}{c}\text { Non-Uncertain } \\
\text { (2) }\end{array}$ & $\begin{array}{l}\text { Uncertain } \\
\text { (3) }\end{array}$ & $\begin{array}{c}\text { Non-Uncertain } \\
\text { (4) }\end{array}$ \\
\hline Overconfident & $0.066^{* * *}$ & $0.061 * *$ & 0.009 & $-0.039 * *$ \\
\hline$R \& D$ & $6.259 * * *$ & $7.065 * * *$ & $-0.644 * * *$ & $-0.951 * * *$ \\
\hline$C A P X$ & $-0.140 * * *$ & $-0.376^{* * *}$ & $0.110 * *$ & 0.053 \\
\hline Market Value & 0.011 & $0.023 * *$ & $-0.023 * * *$ & -0.002 \\
\hline$A d j \_R O A$ & $-0.280 * * *$ & $-0.454 * * *$ & -0.035 & 0.093 \\
\hline Free Cash Flow & $0.290 * * *$ & $0.508 * * *$ & $0.246 * *$ & 0.066 \\
\hline$M \& A$ & $0.227 * * *$ & $0.141^{*}$ & 0.090 & -0.066 \\
\hline Book-to-Market & $-0.045^{* *}$ & $-0.126^{* * *}$ & 0.023 & -0.005 \\
\hline Leverage & $-0.406^{* * *}$ & $-0.598 * * *$ & $0.286^{* * *}$ & $0.173 * * *$ \\
\hline Stock Issuance & 0.007 & 0.007 & $0.097 * * *$ & $0.050 * * *$ \\
\hline Segments & $-0.016^{* * *}$ & 0.002 & $-0.010 * *$ & 0.006 \\
\hline 10-K Length & $0.430 * * *$ & $0.569 * * *$ & $0.691 * * *$ & $0.660 * * *$ \\
\hline Year FE & Yes & Yes & Yes & Yes \\
\hline Industry FE & Yes & Yes & Yes & Yes \\
\hline$R$-Squared & $68.0 \%$ & $70.2 \%$ & $37.8 \%$ & $42.5 \%$ \\
\hline Observations & 22,467 & 22,467 & 22,467 & 22,467 \\
\hline$\chi^{2}$ Test: Overconfident (1) - (2) & 0.06 & & $(3)-(4): 6.63$ & \\
\hline
\end{tabular}


TABLE 9

\section{Historical Investment Disclosure}

This table reports the results from running OLS regressions of the amount of investment disclosure, partitioned by whether the disclosure is historical, on the presence of an overconfident CEO. Panel A (B) reports the results for R\&D (CAPX) disclosure. Significance levels of $10 \%, 5 \%$, and $1 \%$, are represented by $*, * *$, and $* * *$ respectively. Standard errors are clustered by firm. Variable definitions are in Appendix A.

\begin{tabular}{|c|c|c|c|c|}
\hline \multirow{2}{*}{$\begin{array}{l}\text { Panel A: Overconfident-Opt } \\
\text { Disclosure Type: }\end{array}$} & \multicolumn{2}{|c|}{ R\&D Disclosure } & \multicolumn{2}{|c|}{ CAPX Disclosure } \\
\hline & $\begin{array}{c}\text { Non-Historical } \\
\text { (1) }\end{array}$ & $\begin{array}{l}\text { Historical } \\
\text { (2) }\end{array}$ & $\begin{array}{c}\text { Non-Historical } \\
\text { (3) }\end{array}$ & $\begin{array}{c}\text { Historical } \\
\text { (4) }\end{array}$ \\
\hline Overconfident & $0.097 * * *$ & 0.018 & -0.004 & -0.022 \\
\hline$R \& D$ & $6.789 * * *$ & $6.611 * * *$ & $-1.064 * * *$ & -0.321 \\
\hline$C A P X$ & $-0.310 * * *$ & $-0.261 * * *$ & $0.122 * * *$ & -0.053 \\
\hline Market Value & $0.026^{* * *}$ & 0.006 & -0.003 & $-0.023 * * *$ \\
\hline Adj_ROA & $-0.398 * * *$ & $-0.346 * *$ & 0.023 & 0.059 \\
\hline Free Cash Flow & $0.402 * * *$ & $0.405 * * *$ & $0.152 *$ & 0.091 \\
\hline$M \& A$ & $0.197 * *$ & $0.198 * * *$ & -0.052 & -0.001 \\
\hline Book-to-Market & $-0.084 * * *$ & $-0.084 * * *$ & 0.005 & -0.024 \\
\hline Leverage & $-0.504 * * *$ & $-0.449 * * *$ & $0.259 * * *$ & 0.023 \\
\hline Stock Issuance & 0.008 & -0.000 & $0.068 * * *$ & $0.054 * * *$ \\
\hline Segments & -0.005 & -0.001 & 0.000 & 0.004 \\
\hline 10-K Length & $0.589 * * *$ & $0.444 * * *$ & $0.644 * * *$ & $0.740 * * *$ \\
\hline Year FE & Yes & Yes & Yes & Yes \\
\hline Industry FE & Yes & Yes & Yes & Yes \\
\hline$R$-Squared & $69.9 \%$ & $68.8 \%$ & $46.8 \%$ & $27.7 \%$ \\
\hline Observations & 22,467 & 22,467 & 22,467 & 22,467 \\
\hline$\chi^{2}$ Test: Overconfident (1) - (2) & $15.96 * * *$ & & (3) $-(4): 1.05$ & \\
\hline
\end{tabular}




\begin{tabular}{|c|c|c|c|c|}
\hline \multirow{2}{*}{$\begin{array}{l}\text { Panel B: Overconfident-SZ } \\
\text { Disclosure Type: }\end{array}$} & \multicolumn{2}{|c|}{ R\&D Disclosure } & \multicolumn{2}{|c|}{ CAPX Disclosure } \\
\hline & $\begin{array}{c}\text { Non-Historical } \\
\text { (1) }\end{array}$ & $\begin{array}{c}\text { Historical } \\
\text { (2) }\end{array}$ & $\begin{array}{c}\text { Non-Historical } \\
\text { (3) }\end{array}$ & $\begin{array}{c}\text { Historical } \\
\text { (4) }\end{array}$ \\
\hline Overconfident & $0.085 * * *$ & 0.021 & -0.021 & $-0.039^{* *}$ \\
\hline$R \& D$ & $6.803 * * *$ & $6.614 * * *$ & $-1.066 * * *$ & -0.326 \\
\hline$C A P X$ & $-0.303 * * *$ & $-0.259 * * *$ & $0.120 * * *$ & -0.057 \\
\hline Market Value & $0.028 * * *$ & 0.007 & -0.003 & $-0.023 * * *$ \\
\hline Adj_ROA & $-0.400 * * *$ & $-0.346 * *$ & 0.024 & 0.059 \\
\hline Free Cash Flow & $0.419 * * *$ & $0.408 * * *$ & $0.151^{*}$ & 0.087 \\
\hline$M \& A$ & $0.145^{*}$ & $0.183 * * *$ & -0.033 & 0.030 \\
\hline Book-to-Market & $-0.101 * * *$ & $-0.088 * * *$ & 0.007 & -0.018 \\
\hline Leverage & $-0.572 * * *$ & $-0.465 * * *$ & $0.274 * * *$ & 0.052 \\
\hline Stock Issuance & 0.009 & -0.000 & $0.069 * * *$ & $0.055 * * *$ \\
\hline Segments & -0.005 & -0.002 & -0.000 & 0.004 \\
\hline 10-K Length & $0.573 * * *$ & $0.440 * * *$ & $0.648 * * *$ & $0.747 * * *$ \\
\hline Year FE & Yes & Yes & Yes & Yes \\
\hline Industry FE & Yes & Yes & Yes & Yes \\
\hline$R$-Squared & $69.9 \%$ & $68.8 \%$ & $46.7 \%$ & $27.7 \%$ \\
\hline Observations & 22,467 & 22,467 & 22,467 & 22,467 \\
\hline$\chi^{2}$ Test: Overconfident (1) - (2) & $10.83 * * *$ & & $(3)-(4): 0.96$ & \\
\hline
\end{tabular}


The results in Tables 8 and 9 provide support for the view that the increase in R\&D disclosure for firms with overconfident CEOs is driven by an increase in disclosure that is proprietary in nature. Specifically, having an overconfident CEO is associated with a marginally larger increase in the disclosure of uncertain information (compared to non-uncertain information) and a significantly greater increase in the disclosure of non-historical information (compared to historical information). This is consistent with overconfident CEOs perceiving proprietary disclosure costs to be lower, leading to more disclosure of distinctly proprietary R\&D information, which is consistent with the hypothesis. 


\section{CHAPTER VI}

\section{ROBUSTNESS TESTS}

\section{VI.I. CEO-FIRM MATCHING}

An alternative interpretation of the main result is that firms that have, or value, high $R \& D$ disclosure may hire overconfident CEOs more frequently because they possess traits that are more desirable (i.e., the results represent a firm-CEO matching effect and not an overconfidence effect). The propensity score matching results described in section 5.2 and Appendix $\mathrm{C}$ provide evidence that the propensity of a firm to have an overconfident CEO does not appear to substantially affect the main results. Further, since an individual's overconfidence depends on the type of task being performed (such as how difficult the individual perceives the task to be; see Moore and Cain [2007]), it is unlikely that a firm's hiring committee would be able to accurately identify whether a CEO candidate would be overconfident in the CEO role based on whether the individual exhibited overconfidence at his or her prior position (Hsu, Novoselov, and Wang [2017]). This makes it unlikely that firms endogenously choose CEOs based on their overconfidence. However, I perform additional analysis to further parse out whether the results outlined above are due to overconfidence, CEO-firm matching, or both.

Hirshleifer et al. (2012) argue that the time-varying firm characteristics (such as growth opportunities and competitive environment) that might lead to a firm hiring an overconfidence CEO will be strongest in the years closest to the CEO being hired. As such, I follow Hirshleifer et al. (2012) and rerun my main analysis with only firm-years where the CEO has been with the firm for at least four years. The results (untabulated) indicate that the coefficient on Overconfident for the option (SZ) proxy is $0.101(0.061)$ in the main R\&D regression. Results 
for the remaining analyses remain substantially unchanged, lending support for the view that the results are due to $\mathrm{CEO}$ overconfidence and not CEO-firm matching.

\section{VI.II. CEO EQUITY OWNERSHIP}

Nagar, Nanda, and Wysocki (2003) find evidence that CEO's stock-based incentives are associated with firms' disclosure behavior (specifically forecasting). CEO equity ownership may alter the incentives of CEOs to disclose proprietary information as disclosure may impact stock price. I address the concern in two ways. First, I include in the main analysis additional controls for the value of the CEO's firm wealth equal to the natural log of the value of the CEO's stock and option portfolio (in millions) and CEO delta. ${ }^{28}$ Second, I create an indicator variable equal to one when CEO firm wealth is in the top tercile of sample firms in their year and industry and include it as a control for high equity incentives.

The results (untabulated) from the above analysis indicate that CEO equity ownership and incentives are not significantly associated with either R\&D or CAPX disclosure. Further, the coefficients on Overconfident remain substantially unchanged, providing further support that the main results are due to overconfidence and not equity ownership.

\section{VI.III. SIGNIFICANT INVESTMENT LEVELS}

Koh et al. (2017) find that firms with overconfident CEOs are less likely to report no R\&D expense while filings for patents (i.e., have "unreported" R\&D) then firms without an overconfident CEO and are thus more likely to report potentially discretionary amounts of R\&D. This indicates that CEO characteristics may impact the probability that firms report discretionary

${ }^{28}$ Data is acquired from Lalitha Naveen's website: https://sites.temple.edu/lnaveen/data/ and is developed according to the process outlined in Coles, Daniel, and Naveen (2006). 
investment expenditures on the financial statements. If firms with overconfident CEOs are more likely to report $\mathrm{R} \& \mathrm{D}$ expense on the financial statements when it is a discretionary decision, then firms with low amounts of $R \& D$ expense may be driving the results.

To address this concern, I rerun the prior analysis looking only at firms with R\&D scaled by adjusted assets greater than $1 \%$ to reduce the role of discretion in reporting $R \& D$ expense on the financial statements. I find that the association between having an overconfident CEO and R\&D disclosure is larger and with higher statistical significance when only looking at firms with a significant amount of $\mathrm{R} \& \mathrm{D} .{ }^{29}$ This provides evidence that the results do not appear to be due to firms with meaningful R\&D investments being more likely to have an overconfident CEO.

\section{VI.IV. NEW PRODUCT ANNOUNCEMENTS}

One alternative explanation is that overconfident CEOs may invest in different types of projects that are systematically associated with either more successful outcomes or more disclosure (i.e., the results are an investment "type" effect). Unfortunately, it is not possible to observe the specific investment decisions that firms make to completely rule out this explanation. However, I attempt to provide evidence that this does not appear to be the case by testing whether the presence of an overconfident CEO is associated with more R\&D outcomes by examining new product announcements. While still a disclosure choice, new product announcements are more removed from the CEO than other disclosure decisions as they are more likely the result of marketing or sales decisions. If overconfident CEOs are not associated with new product announcements, it can provide some evidence that they do not appear to invest in systematically different investments that leads to more product outcomes.

\footnotetext{
${ }^{29}$ For example, the coefficient on the option (SZ) proxy in the Table 6 analysis is $0.092(0.123)$.
} 
Using data made public by Mukherjee, Singh, and Žaldokas (2017), I test whether overconfident CEOs are associated with a higher number of significant new product announcements (those with the highest announcement returns), or announcements with higher abnormal returns. Specifically, for the subset of years from 2001 to 2006 (the last year of data availability), I regress proxies for new products on the same set of variables included in the tests for the hypothesis. The results in Table 10 indicate that firms with overconfident CEOs do not appear to have systematically different quantity or quality of product announcements than firms with non-overconfident CEOs. 


\section{TABLE 10}

\section{New Product Announcements}

This table reports the results from performing analysis similar to the OLS regression in Table 6, but instead examines product announcements and cumulative abnormal returns around all product announcements in the year instead of R\&D disclosure. Panel A reports the results using the option-based proxy for overconfidence while Panel B reports the results using the Schrand and Zechman proxy. Significance levels of $10 \%, 5 \%$, and $1 \%$, are represented by $* * *$, and *** respectively. Standard errors are clustered by firm. Variable definitions are in Appendix A.

\begin{tabular}{|c|c|c|c|c|}
\hline \multirow{2}{*}{$\begin{array}{l}\text { Panel A: Overconfident-Opt } \\
\text { Dependent Variable: } \\
\text { Overconfident }\end{array}$} & \multicolumn{2}{|c|}{ Product Announcements } & \multicolumn{2}{|c|}{ Product Returns } \\
\hline & 0.010 & 0.002 & -0.000 & -0.001 \\
\hline$R \& D$ & $0.729 * * *$ & $1.007 * * *$ & $0.142 * * *$ & $0.190 * * *$ \\
\hline Controls & No & Yes & No & Yes \\
\hline Year FE & Yes & Yes & Yes & Yes \\
\hline Industry FE & Yes & Yes & Yes & Yes \\
\hline$R$-Squared & $8.1 \%$ & $17.6 \%$ & $8.2 \%$ & $18.4 \%$ \\
\hline Observations & 8,100 & 8,100 & 8,100 & 8,100 \\
\hline \multicolumn{3}{|l|}{$\begin{array}{l}\text { Panel B: Overconfident-SZ } \\
\text { Dependent Variable: }\end{array}$} & \multicolumn{2}{|c|}{ Product Returns } \\
\hline Overconfident & 0.006 & 0.008 & -0.000 & -0.000 \\
\hline$R \& D$ & $0.730 * * *$ & $1.009 * * *$ & $0.142 * * *$ & $0.190 * * *$ \\
\hline Controls & No & Yes & No & Yes \\
\hline Year FE & Yes & Yes & Yes & Yes \\
\hline Industry FE & Yes & Yes & Yes & Yes \\
\hline$R$-Squared & $8.1 \%$ & $17.6 \%$ & $8.2 \%$ & $18.3 \%$ \\
\hline Observations & 8,100 & 8,100 & 8,100 & 8,100 \\
\hline
\end{tabular}




\section{CHAPTER VII}

\section{CONCLUSION}

This paper examines the association between CEO overconfidence and discretionary disclosure of proprietary information. First, I document that narrative R\&D disclosures have greater proprietary disclosure costs then narrative CAPX disclosures. Next, I find evidence consistent with firms with overconfident CEOs disclosing significantly more about R\&D, and not disclosing more about CAPX, then firms without overconfident CEOs. Additional analyses indicate that the increase in $\mathrm{R} \& \mathrm{D}$ disclosure stems from a larger increase in disclosures that convey greater proprietary information (non-historical R\&D related information).

However, this study has two key limitations. First, while robustness analysis provides evidence to the contrary, I cannot completely rule out the alternative explanation that given the same investment levels, firms with overconfident CEOs invest in projects that result in different disclosure amounts. Second, while I rely on prior literature to motivate using a sentence-based measure of disclosure in the $10-\mathrm{K}$ for my main analysis, it does have the limitation of being a relatively crude proxy for the amount of disclosure. Specifically, it does not allow for capturing subtleties contained in the disclosure or disclosures made through alternative channels.

The findings in this paper are consistent with overconfidence altering a CEO's perspective of the proprietary costs of disclosure, resulting in relatively more disclosure of proprietary information. This paper sheds light on an alternative explanation than the literature that argues that overconfident CEOs are better innovators (e.g., Galasso and Simcoe [2011] and Hirshleifer et al. [2012]) by showing that overconfidence is associated with more R\&D disclosure. To the extent that prior measures of innovation outcomes (i.e., patents) are at least 
partially a disclosure choice, these findings suggest that the association between overconfidence and innovation may instead be due to overconfident CEOs underestimating disclosure costs. This study provides some of the first evidence that CEO characteristics are an important determinant of the disclosure of proprietary information in areas outside of management forecasts. Further, this study increases our understanding of how managers make narrative investment disclosure decisions, an important disclosure avenue for communicating information that is not effectively conveyed through financial statement numbers alone. 


\section{REFERENCES}

Albring, S., Banyi, M., Dhaliwal, D., Periera, R., 2016. Does the firm information environment influence financing decisions? A test using disclosure regulation. Management Science 62 (2), 456-478.

Ahmed, A.S., Duellman, S., 2012. Managerial overconfidence and accounting conservatism. Journal of Accounting Research 51 (1), 1-30.

Allison, J.R., Lemley, M.A., Schwartz, D.L., 2014. Understanding the realities of modern patent litigation. Texas Law Review 92, 1769-1801.

Anderson, C., Brion, S., Moore, D.A., Kennedy, J.A., 2012. A status-enhancement account of overconfidence. Journal of Personality and Social Psychology 103 (4), 718-735.

Beyer, A., Cohen, D.A., Lys, T.Z., Walther, B.R., 2010. The financial reporting environment: Review of the recent literature. Journal of Accounting and Economics 50, 296-343.

Beyer, B., Herrmann, D., Rapley, E.T., 2015. Disaggregated capital expenditures. Working Paper.

Bloom, N., Schankerman, M., Van Reenen, J., 2013. Identifying technology spillovers and product market rivalry. Econometrica 81 (4), 1347-1393.

Boone, A.L., Floros, I.V., Johnson, S.A., 2016. Redacting proprietary information at the initial public offering. Journal of Financial Economics 120, 102-123.

Brown, S.V., Tucker, J.W., 2011. Large-sample evidence on firms' year-over-year MD\&A modifications. Journal of Accounting Research 49 (2) 309-346.

Campbell, T.C., Gallmeyer, M., Johnson, S.A., Rutherford, J., Stanley, B.W., 2011. CEO optimism and forced turnover. Journal of Financial Economics 101, 695-712.

Ciftci, M., Zhou, N., 2016. Capitalizing R\&D expenses versus disclosing intangible information. Review of Quantitative Finance and Accounting 46 (3), 661-689.

Cole, C.J., Jones, C.L., 2015. The quality of management forecasts of capital expenditures and store openings in MD\&A. Journal of Accounting, Auditing \& Finance 30 (2), 127-149. 
Coles, J., Daniel, N.D., Naveen, L., 2006. Managerial incentives and risk-taking. Journal of Financial Economics 79 (2), 431-468.

Curtis, A., McVay, S., Toynbee, S., 2017. The changing implications of research and development expenditures for future profitability. Working Paper.

Dedman, E., Lennox, C., 2009. Perceived competition, profitability and the withholding of information about sales and the cost of sales. Journal of Accounting and Economics 28, 210-230.

Dye, R.A., 1986. Proprietary and nonproprietary disclosures. The Journal of Business 59 (2), 331-366.

Ellis, J.A., Fee, E., Thomas, S.E., 2012. Proprietary costs and the disclosure of information about customers. Journal of Accounting Research 50 (3), 685-727.

Entwistle, G.M., 1999. Exploring the R\&D disclosure environment. Accounting Horizons 13 (4), 323-341.

Galasso, A., Simcoe, T.S., 2011. CEO overconfidence and innovation. Management Science 57 (8), 1469-1484.

Gigler, F., 1994. Self-enforcing voluntary disclosures. Journal of Accounting Research 32 (2), 224-240.

Glaeser, S., Michels, J., Verrecchia, R.E., 2017. Discretionary disclosure and manager horizon. Working Paper.

Graham, J.R., Harvey, C.R., Rajgopal, S., 2005. The economic implications of corporate financial reporting. Journal of Accounting and Economics 40, 3-73.

Hall, B.J., Murphy, K.J., 2002. Stock options for undiversified executives. Journal of Accounting and Economics 33, 3-42.

Harris, M.S., 1998. The association between competition and managers' business segment reporting decisions. Journal of Accounting Research 36 (1), 111-128.

Heaton, J.B., 2002. Managerial optimism and corporate finance. Financial Management 31 (2), $33-45$.

Hendricks, B.E., Lang, M.H., Merkley, K.J., 2017. Through the eyes of the founder: CEO characteristics and firms' regulatory filings. Working Paper. 
Hilary, G., Hsu, C., 2011. Endogenous overconfidence in managerial forecasts. Journal of Accounting and Economics 51, 300-313.

Hirshleifer, D., Low, A., Teoh, S.H., 2012. Are overconfident CEOs better innovators? The Journal of Finance LXVII (4), 1457-1498.

Hoberg, G., Phillips, G., 2016. Text-based network industries and endogenous product differentiation. Journal of Political Economy 124 (5), 1423-1465.

Hope, O., Hu, D., Lu, H., 2016. The benefits of specific risk-factor disclosures. Review of Accounting Studies 21, 1005-1045.

Hribar, P., Yang, H., 2016. CEO overconfidence and management forecasting. Contemporary Accounting Research 33 (1), 204-227.

Hsu, C., Novoselov, K.E., Wang, R., 2017. Does accounting conservatism mitigate the shortcomings of CEO overconfidence? The Accounting Review 92 (6), 77-101.

Huang, Y., Jennings, R., Yu, Y., 2017. Product market competition and managerial disclosure of earnings forecasts: Evidence from import tariff rate reductions. The Accounting Review 92 (3), 185-207.

Jackson, S.B., 2008. The effect of firms' depreciation method choice on managers' capital investment decisions. The Accounting Review 83 (2), 351-376.

Jackson, S.B., Liu, X., Cecchini, M., 2009. Economic consequences of firms' depreciation method choice: Evidence from capital investments. Journal of Accounting and Economics 48, 54-68.

James, S.D., Shaver, J.M., 2016. Motivations for voluntary public R\&D disclosures. Academy of Management Discoveries 2 (3), 290-312.

Johnson, D. D. P. (2004). Overconfidence and war: The havoc and glory of positive illusions. Cambridge, MA: Harvard University Press.

Jones, D.A., 2007. Voluntary disclosure in R\&D-intensive industries. Contemporary Accounting Research 24 (2), 489-522.

Kim, J., Wang, Z., Zhang, L., 2016. CEO overconfidence and stock price crash risk. Contemporary Accounting Research 33 (4), 1720-1749. 
Klette, T.J., Griliches, Z., 2000. Empirical patterns of firm growth and R\&D investment: A quality ladder model interpretation. The Economic Journal 110, 363-387.

Koellinger, P., Minniti, M., Schade, C., 2007. "I think I can, I think I can": Overconfidence and entrepreneurial behavior. Journal of Economic Psychology 28, 502-527.

Koh, P., Reeb, D.M., 2015. Missing R\&D. Journal of Accounting and Economics 60, 73-94.

Koh, P., Reeb., B.M., Zhao, W., 2017. CEO confidence and unreported R\&D. Management Science, Forthcoming.

Lehavy, R., Li, F., Merkley, K., 2011. The effect of annual report readability on analyst following and the properties of their earnings forecasts. The Accounting Review 86 (3), 1087 1115.

Lev, B., Radhakrishnan, S., Tong, J.Y., 2016. R\&D volatility drivers. Working Paper.

Li, F., 2010. The information content of forward-looking statements in corporate filings - A naïve Bayesian machine learning approach. Journal of Accounting Research 48 (5), 1049-1102.

Li, X., 2010. The impacts of product market competition on the quantity and quality of voluntary disclosures. Review of Accounting Studies 15, 663-711.

Loughran, T., McDonald, B., 2016. Textual analysis in accounting and finance: A survey. Journal of Accounting Research 54 (4), 1187-1230.

Malmendier, U., Tate, G., 2005. CEO overconfidence and corporate investment. The Journal of Finance LX (6), 2661-2700.

Malmendier, U., Tate, G., 2008. Who makes acquisitions? CEO overconfidence and the market's reaction. Journal of Financial Economics 89, 20-43.

Malmendier, U., Tate, G., 2015. Behavioral CEOs: The role of managerial overconfidence. Journal of Economic Perspectives 29 (4), 37-60.

Merkley, K., 2014. Narrative disclosure and earnings performance: Evidence from R\&D disclosures. The Accounting Review 89 (2), 725-757.

Moore, D.A., Cain, D.M., 2007. Overconfidence and underconfidence: When and why people underestimate (and overestimate) the competition. Organizational Behavior and Human Decision Processes 103, 197-213. 
Mukherjee, A., Singh, M., Žaldokas, A., 2017. Do corporate taxes hinder innovation? Journal of Financial Economics 124 (195-221).

Muslu, V., Radhakrishnan, S., Subramanyam, K.R., Lim, D., 2015. Forward-looking MD\&A disclosures and the information environment. Management Science 61 (5), 931-948.

Nagar, V., Nanda, D., Wysocki, P., 2003. Discretionary disclosure and stock-based incentives. Journal of Accounting and Economics 34, 283-309.

Palmon, D., Yezegel, A., 2012. R\&D intensity and the value of analysts' recommendations. Contemporary Accounting Research 29 (2), 621-654.

Phua, K., Tham, T.M., Wei, C., 2018. Are overconfident CEOs better leaders? Evidence from stakeholder commitments. Journal of Financial Economics 127, 519-545.

PricewaterhouseCoopers, 2016. 2016 Patent Litigation Study: Are we at an inflection point? Retrieved from: http://www.pwc.com/us/en/forensic-services/publications/assets/2016-pwcpatent-litigation-study.pdf

Saidi, F., Žaldokas, A., 2017. How does firms' innovation disclosure affect their banking relationships? Working Paper.

Schrand, C.M., Zechman, S.L.C., 2012. Executive overconfidence and the slippery slope to financial misreporting. Journal of Accounting and Economics 53, 311-329.

Shipman, J.E., Swanquist, Q.T., Whited, R.L., 2017. Propensity score matching in accounting research. The Accounting Review 92 (1), 213-244.

Simpson, A., 2008. Voluntary disclosure of advertising expenditures. Journal of Accounting, Auditing \& Finance 23 (3), 403-436.

Skała, D., 2008. Overconfidence in psychology and finance-An interdisciplinary literature review. Bank i Kredyt 4, 33-50.

Verrecchia, R.E., 1983. Discretionary disclosure. Journal of Accounting and Economics 5, 179194. 


\section{APPENDIX A}

\section{VARIABLE DESCRIPTIONS}

Adjusted Assets

Market Value

Revenue

$R \& D$

$C A P X$

Adjusted ROA

Free Cash Flow

$M \& A$

Book-to-Market

Leverage

Stock Issuance

Segments

10-K Length
$=$ Total assets minus net PPE (AT - PPENT).

$=$ The natural log of market value at fiscal yearend (from CRSP).

$=$ The natural log of total revenue (REVT).

$=\mathrm{R} \& \mathrm{D}$ expense scaled by adjusted assets (XRD/Adjusted Assets).

$=$ Capital expenditures scaled by adjusted assets (CAPX/Adjusted Assets).

$=$ Net income plus depreciation and $R \& D$ expense scaled by adjusted assets ((NI + DP + XRD)/Adjusted Assets $)$.

$=$ Income before extraordinary items plus depreciation scaled by adjusted assets ((IB + DP)/Adjusted Assets).

$=$ Acquisitions from the statement of cash flows scaled by adjusted assets (AQC/Adjusted Assets).

$=$ Book value scaled by market value at fiscal yearend ((SEQ PSTKL + TXDITC + PRBA)/Market Value).

$=$ Total liabilities scaled by total assets $((\mathrm{DLTT}+\mathrm{DLC}) / \mathrm{AT})$.

$=1$ if the firm sold more stock during the year than they purchased (SSTK $>$ PRSTKC).

$=$ Number of business and operating segments in the Compustat segment file.

$=$ The natural log of the number of sentences in the $10-\mathrm{K}$. 
$R \& D$ Disclosure

High R\&D Disclosure

CAPX Disclosure

High CAPX Disclosure

Overconfident-Opt

Overconfident-SZ
$=$ The natural $\log$ of $1+$ the number of sentences in the $10-\mathrm{K}$ that are identified as being $R \& D$ related. A sentence is $R \& D$ related if it contains at least one of the phrases listed in Appendix B.

$=1$ if the firm is in the top tercile of $R \& D$ Disclosure in their year and industry.

$=$ The natural $\log$ of $1+$ the number of sentences in the $10-\mathrm{K}$ that are identified as being capital investment related. A sentence is capital investment related if it contains at least one of the phrases listed in Appendix B.

$=1$ if the firm is in the top tercile of CAPX Disclosure in their year and industry.

$=1$ after the first year a CEO holds exercisable options with an average moneyness of at least $100 \%$ if the CEO holds $100 \%$ inthe-money options at least twice during the CEO's tenure at the firm (following Campbell et al. [2011]).

$=1$ after the first year in a CEO's tenure where three of the following five criteria are satisfied: (1) excess investment (measures as the residual from regressing asset growth on sales growth) is in the top quartile of firms in the industry-year; (2) net dollars of acquisitions (from the statement of cash flows) are in the top quartile of firms in the industry-year; (3) the debt-toequity ratio is in the top quartile of firms in the industry-year; (4) the firm utilizes either convertible debt or preferred stock; and (5) 
the firm paid no dividends in the year (following Schrand and Zechman [2012] as implemented by Kim et al. [2016]).

Competition

Adjusted 3-Year Earnings

Adjusted 5-Year Earnings

Adjusted ROA Growth

Product Announcements

Product Returns
$=$ The Hoberg-Phillips (2016) product market competition measure (a modified Herfindahl-Hirschman Index) multiplied by negative one such that it ranges from -1 (low competition) to 0 (high competition).

$=$ The sum of adjusted net income from year $t+1$ to $t+3$ scaled by Adjusted Assets.

$=$ The sum of adjusted net income from year $t+1$ to $t+5$ scaled by Adjusted Assets.

$=$ The difference between current adjusted net income and lagged adjusted net income scaled by Adjusted Assets.

$=$ The natural $\log$ of $1+$ the number of significant new product announcements (those with announcement returns greater than the $75^{\text {th }}$ percentile for the year) over the year. Data provided by Mukherjee et al. (2017) and is only available until 2006.

$=$ The sum of the cumulative 3-day abnormal returns around new product announcements over the year. Data provided by Mukherjee et al. (2017) and is only available until 2006. 


\section{APPENDIX B}

\section{INVESTMENT PHRASES}

This appendix lists the phrases used to classify sentences as being either R\&D or CAPX related. I thank Kenneth Merkley for graciously providing the list of R\&D phrases used in his 2014 study. The list of CAPX phrases was developed by analyzing 100 10-Ks of firms sampled from both CAPX and non-CAPX intensive industries. I further examined random 10-Ks of firms in the highest and lowest percentile of CAPX disclosure to ensure that the phrase list was appropriately identifying investment related sentences and to reduce Type I and Type II errors.

\section{R\&D Phrases:}

research and development

$\mathrm{R} \& \mathrm{D}$

product development

research, development

research, engineering, and

development

research development

research project

research and evaluation

project

research program

research collaboration

research facility

research facilities

research initiative

research venture

research center

conduct research

new technology

joint research

develop technology

entering development

developing new products

development of new products research operations

research pipeline

product engineering

technology development

technical development

technology milestone

technology breakthrough

technological breakthrough

breakthrough innovation

clinical candidate

product candidate

drug candidate

breakthrough in

developing new technologies

development of proprietary technology

established a collaboration

projects in development

completion of key milestones

continuing development of

preclinical development

preclinical data

evaluating the potential of clinical data

clinical development

clinical program

clinical study

safety study

pilot study

announced a collaboration

joint venture to develop

collaborative initiative

collaborative research

research collaborative

applied for patent

claims in this patent

filed patent

granted a patent

issued a patent

new patent

received a patent

patent was awarded

key patent

important patent

patents pending

applications pending 
Capital Investment Phrases:

building expansion

buildings

capital equipment

capital expansion

capital expenditure

capital expense

capital improvement cost

capital investment

capital project

capital spending

equipment and machinery

equipment and property

equipment, furniture expansion of our facilities

expansion of our facility

improve existing facilities

investment in equipment

investment in machinery

investments in equipment

investments in machinery

leasehold improvement

machinery and equipment

manufacturing equipment

manufacturing facilities

manufacturing sites

new store plants

production equipment

properties and facilities

property and equipment

property improvement

property, furniture

property, plant

significant construction

warehouse

PPE

PP\&E

CAPX

CAPEX 


\section{APPENDIX C}

\section{PROPENSITY SCORE MATCHING ANALYSIS}

My main results may be caused by differences in firms with and without an overconfident CEO (e.g., differences in available or chosen investment projects), and thus the models may be biased due to identification issues related to functional form misspecification (FFM) ${ }^{30}$ To mitigate this concern, I utilize propensity score matching (PSM) techniques to identify a group of firms with similar observable characteristics and rerun the primary analysis for the main hypothesis (i.e., I perform what is commonly called "doubly robust estimation." See Shipman, Swanquist, and Whited [2017] for further discussion). In addition to the primary PSM tests outlined in section 4.3, I run three different models requiring that the control firms come from the subset of observations within the same industry-year, allowing for replacement, and increasing the caliper to 0.10 .

Table $\mathrm{C} 1$ reports the results from the first-stage logit regression used to determine the propensity of a firm having an overconfident CEO for both proxies of overconfidence. The pseudo $\mathrm{R}^{2}$ for both models is relatively low (under 14\%) indicating that firms with overconfident CEOs do not differ on observable characteristics in a highly predictable manner. Shipman et al. (2017) note that having low explanatory power in the first-stage model does not necessarily mean that PSM will be ineffective. Low explanatory power is indicative of a high degree of overlap between treated (overconfident CEOs) and non-treated (non-overconfident CEO) observations which allows for a larger sample size and greater generalizability beyond the

\footnotetext{
${ }^{30} \mathrm{FFM}$ is a more significant issue the more different firms with and without overconfident CEOs are. The ideal scenario would be that overconfident CEOs are randomly assigned to firms. However, this is unlikely to be the case empirically.
} 
matched subsample. However, low predictive power also means that the resulting matched sample may be more likely to represent a random subsample rather than a representative control group. For all three PSM models there is substantial overlap between firms with and without an overconfident CEO in the propensity to have an overconfident CEO.

Table $\mathrm{C} 2$ reports the results from the second-stage OLS regression (i.e., the "doubly robust estimation" results). Panel A reports the results for R\&D disclosure while Panel B reports the results for CAPX disclosure. The results are consistent with the regressions performed in Tables 6 and 7 and provide further support that firms with overconfident CEOs disclose more about R\&D activities and not more about CAPX activities. 
TABLE C1

\section{Additional Propensity Score Matching Models}

This table reports the results from the first stage logit model used in the propensity score models. Significance levels of $10 \%, 5 \%$, and $1 \%$, are represented by $*$, **, and $* * *$ respectively. Standard errors are clustered by firm. Variable definitions are in Appendix A.

\begin{tabular}{l|c|c}
$\begin{array}{l}\text { Panel A (First Stage): } \\
\text { Dependent Variable: }\end{array}$ & \multicolumn{1}{l}{ Overconfident-Opt } & Overconfident-SZ \\
\hline R\&D & 0.384 & -0.383 \\
CAPX & -0.132 & $-0.638^{* * *}$ \\
Market Value & $0.101^{* * *}$ & 0.042 \\
Adj_ROA & -0.050 & 0.158 \\
Free Cash Flow & 0.650 & -0.328 \\
M\&A & $1.469^{* * *}$ & $4.892^{* * *}$ \\
Book-to-Market & $-0.507^{* * *}$ & $0.467^{* * *}$ \\
Leverage & $-0.635^{* * *}$ & $3.325^{* * *}$ \\
Stock Issuance & $0.124^{* *}$ & $0.143^{* * *}$ \\
Segments & $-0.075^{* * *}$ & $-0.046^{* * *}$ \\
10-KLEngth & -0.164 & $0.811^{* * *}$ \\
& & \\
Year FE & Yes & Yes \\
Industry FE & Yes & Yes \\
Pseudo R-Squared & $5.1 \%$ & $13.5 \%$ \\
Observations & 22,432 & \\
& &
\end{tabular}


TABLE C2

\section{Additional Propensity Score Matching Models}

This table reports the results from running the three additional PSM models outlines in Appendix

C. Balanced Covariates reports the number of control variables where the p-value for the difference in means between firms with and without an overconfident CEO is $>0.01$. Significance levels of $10 \%, 5 \%$, and $1 \%$, are represented by $*$, $* *$, and $* * *$ respectively. Standard errors are clustered by firm. Variable definitions are in Appendix A.

\begin{tabular}{|c|c|c|c|c|c|c|}
\hline \multirow{3}{*}{$\begin{array}{l}\text { Panel A: } \\
\text { R\&D Disclosure } \\
\text { Model: }\end{array}$} & \multicolumn{3}{|c|}{ Overconfident-Opt } & \multicolumn{3}{|c|}{ Overconfident-SZ } \\
\hline & Within & With & Caliper $=$ & Within & With & Caliper $=$ \\
\hline & Ind-Year & Replacement & 0.10 & Ind-Year & Replacement & 0.10 \\
\hline Overconfident & $0.101 * * *$ & $0.069 * *$ & $0.072 * * *$ & $0.054 *$ & $0.086 * * *$ & $0.074 * * *$ \\
\hline$R \& D$ & $7.060 * * *$ & $7.429 * * *$ & $7.433 * * *$ & $7.218 * * *$ & $7.137 * * *$ & $7.248 * * *$ \\
\hline$C A P X$ & $-0.420 * * *$ & $-0.437 * * *$ & $-0.414 * * *$ & $-0.400 * * *$ & $-0.447 * * *$ & $-0.429 * * *$ \\
\hline Market Value & $0.028 * *$ & 0.017 & $0.019 *$ & $0.042 * * *$ & $0.030 * * *$ & $0.030 * * *$ \\
\hline Adj_ROA & $-0.511 * *$ & $-0.751 * * *$ & $-0.697 * * *$ & $-0.538 * *$ & $-0.536 * * *$ & $-0.522 * * *$ \\
\hline Free Cash Flow & $0.540 * * *$ & $0.811^{* * *}$ & $0.778 * * *$ & $0.520 * *$ & $0.556^{* * *}$ & $0.550 * * *$ \\
\hline$M \& A$ & $0.274 * *$ & 0.143 & $0.236^{* *}$ & $0.439 * *$ & 0.092 & $0.342 * * *$ \\
\hline Book-to-Market & $-0.108 * * *$ & $-0.128 * * *$ & $-0.115 * * *$ & $-0.066^{*}$ & $-0.074 * * *$ & $-0.094 * * *$ \\
\hline Leverage & $-0.698 * * *$ & $-0.611 * * *$ & $-0.600 * * *$ & $-0.801 * * *$ & $-0.650 * * *$ & $-0.659 * * *$ \\
\hline Stock Issuance & -0.013 & 0.003 & -0.004 & 0.026 & 0.025 & 0.015 \\
\hline Segments & -0.002 & -0.000 & 0.001 & -0.012 & 0.001 & -0.006 \\
\hline 10-K Length & $0.683 * * *$ & $0.670 * * *$ & $0.670 * * *$ & $0.659 * * *$ & $0.686 * * *$ & $0.660 * * *$ \\
\hline $\begin{array}{l}\text { Balanced } \\
\text { Covariates }\end{array}$ & $11 / 11$ & $3 / 11$ & $9 / 11$ & $6 / 11$ & $3 / 11$ & $9 / 11$ \\
\hline Year FE & Yes & Yes & Yes & Yes & Yes & Yes \\
\hline Industry FE & Yes & Yes & Yes & Yes & Yes & Yes \\
\hline R-Squared & $73.3 \%$ & $72.6 \%$ & $72.8 \%$ & $72.4 \%$ & $73.2 \%$ & $72.5 \%$ \\
\hline Observations & 10,152 & 15,768 & 15,118 & 7,266 & 15,928 & 12,508 \\
\hline
\end{tabular}




\begin{tabular}{|c|c|c|c|c|c|c|}
\hline $\begin{array}{l}\text { Panel B: } \\
\text { CAPX } \\
\text { Disclosure }\end{array}$ & \multicolumn{3}{|c|}{ Overconfident-Opt } & \multicolumn{3}{|c|}{ Overconfident-SZ } \\
\hline Model: & $\begin{array}{l}\text { Within } \\
\text { Ind-Year }\end{array}$ & With & Caliper $=$ & $\begin{array}{l}\text { Within } \\
\text { Ind-Year }\end{array}$ & With & Caliper $=$ \\
\hline Overconfident & -0.000 & -0.015 & -0.009 & -0.030 & -0.029 & -0.029 \\
\hline$R \& D$ & $-0.973 * * *$ & $-0.818 * * *$ & $-0.853 * * *$ & $-0.834 * * *$ & $-0.821 * * *$ & $-0.756 * * *$ \\
\hline$C A P X$ & $0.101 * *$ & 0.038 & 0.060 & 0.101 & $0.098^{*}$ & $0.097 *$ \\
\hline Market Value & -0.004 & 0.001 & -0.002 & -0.004 & -0.010 & -0.008 \\
\hline Adj_ROA & 0.150 & 0.059 & 0.075 & $0.249 *$ & 0.127 & 0.143 \\
\hline Free Cash Flow & 0.070 & 0.135 & 0.148 & 0.078 & 0.019 & 0.022 \\
\hline$M \& A$ & 0.031 & 0.051 & 0.026 & 0.011 & -0.016 & -0.015 \\
\hline Book-to-Market & -0.008 & 0.011 & 0.016 & -0.033 & -0.025 & -0.015 \\
\hline Leverage & $0.198 * * *$ & $0.127 * *$ & $0.172 * * *$ & $0.298 * * *$ & $0.160 * * *$ & $0.172 * * *$ \\
\hline Stock Issuance & $0.068 * * *$ & $0.061 * * *$ & $0.063 * * *$ & $0.080 * * *$ & $0.068 * * *$ & $0.068^{* * *}$ \\
\hline Segments & -0.002 & -0.002 & -0.002 & 0.003 & 0.005 & 0.004 \\
\hline 10-K Length & $0.705 * * *$ & $0.727 * * *$ & $0.721 * * *$ & $0.702 * * *$ & $0.723 * * *$ & $0.697 * * *$ \\
\hline $\begin{array}{l}\text { Balanced } \\
\text { Covariates }\end{array}$ & $11 / 11$ & $3 / 11$ & $9 / 11$ & $6 / 11$ & $3 / 11$ & $9 / 11$ \\
\hline Year FE & Yes & Yes & Yes & Yes & Yes & Yes \\
\hline Industry FE & Yes & Yes & Yes & Yes & Yes & Yes \\
\hline R-Squared & $49.0 \%$ & $46.9 \%$ & $47.9 \%$ & $47.4 \%$ & $45.0 \%$ & $45.9 \%$ \\
\hline Observations & 10,152 & 15,768 & 15,118 & 7,266 & 15,928 & 12,508 \\
\hline
\end{tabular}

